\title{
Factors affecting average grain size changes in rivers of a catchment area (Ardak catchment area, northeast Iran)
}

\author{
Mohammad Javanbakht $^{1} \cdot$ Mohammad Reza Beheshtipur $^{1} \cdot$ Shima Raftari Farimani $^{1}$
}

Received: 22 April 2021 / Accepted: 25 September 2021 / Published online: 2 March 2022

(c) Saudi Society for Geosciences 2022

\begin{abstract}
Investigation of sediment control factors in river channels of a catchment can play a very important role in the sustainable management of that catchment. For this purpose, Ardak catchment was selected, on which a reservoir dam was constructed for drinking and agricultural purposes large city of Mashhad in northeastern Iran. Then 57 samples were collected from the surface to the depth of $30 \mathrm{~cm}$ along the four rivers: A (14), B (23), C (13), and D (7). The samples were subsequently weighed and sieved for particle-size distribution. Cumulative curves were plotted followed by the determination of statistical parameters. Thirty-four representative fresh samples were selected for study using macroscopic features. Lithofacies were identified in the field using parametersand their mutual association following the classification scheme of Walker and Cant and Miall. Data on the textural parameters of different rivers showed that rivers A, D, B, and C produce coarse sediments. In terms of average grain size, river A has a greater role in the production of gravel sediments and river B has a greater role in the production of sand and mud sediments. According to the studies, the effect of formation of this catchment (Mozduran 3, Tirgan, and Mozduran 1) on the production of gravel sediments and other formation (Chaman Bid, Sarcheshmeh, and Shurijeh) which include more shale layers is more in the production of sand and mud sediments. Examination of sedimentary facies of alluvial terraces shows that river B is more effective in producing gravelly sediments and river A is more effective in producing sandy and mud sediments. Finally, a comparison of average grain size in sediments formed in the riverbeds of this catchment area and a comparison of this parameter in past sedimentary facies can show the effect of tectonic activity as the most important factor controlling textural parameters in this basin over time.
\end{abstract}

Keywords Ardak basin · NE Iran · Sedimentary facies · Grain size analysis

\section{Introduction}

The relative importance of the factors responsible for catchment area and sediments formation and evolution is still poorly understood. The relative importance of tectonics, climate, base level, and source lithology as primary factors on catchment evolution and sedimentary style remain

Responsible Editor: Attila Ciner

Mohammad Javanbakht

mo_ja85@yahoo.com

Mohammad Reza Beheshtipur

mr-beheshty@yahoo.com

Shima Raftari Farimani

shima.raftarii@gmail.com

1 Department of Geology, Mashhad Branch, Islamic Azad University, Mashhad, Iran in question (Shukla et al., 2001; Chakraborty and Ghosh 2010; Hartley et al., 2010; Singh et al, 2018). However, sediment supply, which is a key factor behind the alluvial formation, is controlled by catchment lithology (Leece, 1991; Levson and Rutter, 2000; Hartley et al., 2005; Wagreich and Strauss, 2005). Active tectonics controls the location of sediments while passive tectonics can control the configuration of the catchment drainage network and its bedrock geology (Quigley et al., 2007; Salcher et al., 2010), but climate tends to control alluvial-fan sequences (Bull, 1991; Weissmann et al., 2002; Harvey et al. 2005; Eppes and McFadden, 2008; Clarke et al., 2010; Waters et al., 2010; Chand et al., 2019). However, different rocks types will weather differently giving rise to different sediment supply for the same climate regime (Calvache et al., 1997; Blair, 1999; Wagreich and Strauss, 2005; Juez et al., 2018).

Although alluvial are clearly related to the emergence of a large mountain river onto a low-relief alluvial plain, their 
stratigraphic evolution depends on variables such as source catchment characteristics, water discharge, sediment flux, and subsidence rate, factors that are ultimately controlled by tectonic, climate, and geomorphic processes (Gupta, 1997; Horton and DeCelles, 2001; Leier et al., 2005; Quigley et al., 2007; Goswami et al., 2009). It has long been realized that the factors which control catchment morphology include its characteristics (such as basin area drainage, relief, and geology) sediment and water volume, and therefore the process regime on the alluvial and the resulting alluvial morphology (Silva et al. 1992; Calvache et al. 1997; Harvey et al.1999; Harvey, 2002; Viseras et al. 2003; Juez et al., 2018). Information on catchment size, shape, and relief are important in attempting to quantify and model sediment fluxes and routing them into sedimentary basins. Sediment enters the sedimentary basins from catchment areas located within the bounding mountain ranges at point sources located at the basin margins (Mather et al. 2000; Kanhaiya, et al., 2017). Beaumont (1972) evaluated the evolution and hydrological conditions of 26 alluvial and their drainage basins in the southern margin of Alburz Mountains, SE Tahran. Arzani (2005) studied in detail the morphology as well as the facies distribution of the fluvial megafan of Abarkoh Basin, Central Iran. At his 2012 study, it was investigated the control of catchment lithology on the development of the Soh and Zefreh alluvial megafans in the Kohrud mountain range, Central Iran. He also found that significant reorganization of drainage networks can occur through streamflow and debris sedimentation in mountain areas affected by uplift. This modification can dramatically affect sediment flux and routing into adjacent megafans. It is thus important to obtain information on rates and direction of changes in catchment areas in such environments. Since this catchment ends in the alluvial and water reservoir of Ardak, the purpose of this paper is to investigate and document the differences in textural parameters between different channels in the catchment of Ardak Mountain, northeastern Iran, which is influenced by river flow and geological features. Also, the sedimentary facies of the studied canals and the effect of basin lithology and flow characteristics on the sediments entering the dam reservoir and fan evolution in the arid lands of the Duck Basin have been investigated.

\section{Geological setting}

Shortening and deformation in the Iranian zone were caused by the movement of the Arabian plate towards Eurasia. New GPS measurements show that this is moving forward the north about $23 \mathrm{~mm}$ per year (Hollingsworth, 2007). Part of this shortening in the form of folds, thrusts, and sliding systems in the Kopet Dagh will be compensated.
Kopet Dagh sedimentary basin after collision of Iran and the Turan plates (part of shield Eurasia) and the closure of the ancient Tethys Ocean caused by the Siminite event in the late Triassic emerged. Post-Triassic deposits with an important regional unconformity on the units are older (Aghanabati, 2004) (Fig. 1). These deposits extend over much of the Caucasus to northern Afghanistan formed in a tidal basin (Thomas et al., 1999). The Kopet Dagh Basin continues southeast of the Southern Caspian Basin and the deepest part of the Southern Caspian Basin. It is in the Caspian Sea where there is still an oceanic crust. Openness this sedimentary basin to the southeast is like a zipper (Thierry, 2000; Taheri et al., 2006; Javanbakht et al., 2013). Hence, the depth and extent of this basin decrease from northwest to southeast, according to many researchers, the southern boundary of the Kopet Dagh as well as the seam of ancient Tethys along with the Atrak-Kashkarud Valley (Stöcklin, 1968; Berberian and king, 1981; Alavi, 1991; Sheikholeslami and Kouhpeyma, 2012; Zanchetta et al., 2013; Robert et al., 2014, Zanchi et al., 2015). Therefore, the Kopet Degh rock, as well as the Paleozoic and Triassic outcrops of the Aghdarband window, are part of the Turan plate. However, Eftekharnejad and Behroozi (1991) consider the ancient rocks of the Agdarband window as other parts of Alborz and the existence of the seam of ancient Tethys archers reject this area. They believe that the Kopet Dagh area is part of the Iranian plate. Also, Trifonov (1978) considers Ashgabat fault in Turkmenistan which is extended to Sarakhs region in Iran as a separator of Kopet Dagh rang from Turan range.

Ardak catchment is located in the north of Khorasan Razavi province and in the north of Chenaran city and part of the Kashfarud river catchment. Geologically, this catchment is located in the structural sedimentary zone of Kopet Dagh (Aghanabati, 2004).

Geologically, this catchment is located in the KopetDagh structural sedimentary zone (Aghanabati 2004). Therefore, its stratigraphic and structural process is in line with the Kopet-Dagh sedimentary basin, which begins in the W-NW to E-SE in the east of the Caspian Sea and enters the territory of Afghanistan after crossing Turkmenistan and Iran (Javanbakht et al., 2018). Its oldest rocks are from Jurassic period (Mozduran Formation 1) and the youngest of them are alluvial deposits of river bed. From the stratigraphic point of view, the Mozduran 1 Formations (with dolomitic lithology) (Fig. 3C), Chaman Bid (with marl lithology and thin-layer lime) (Fig. 3D), Mozduran Formation 2 (with thick layer-to-mass lithology and dolomitic lime) (Fig. 3D), Shourijeh formation (with sandstone, conglomerate, shale, limestone, and marl) 


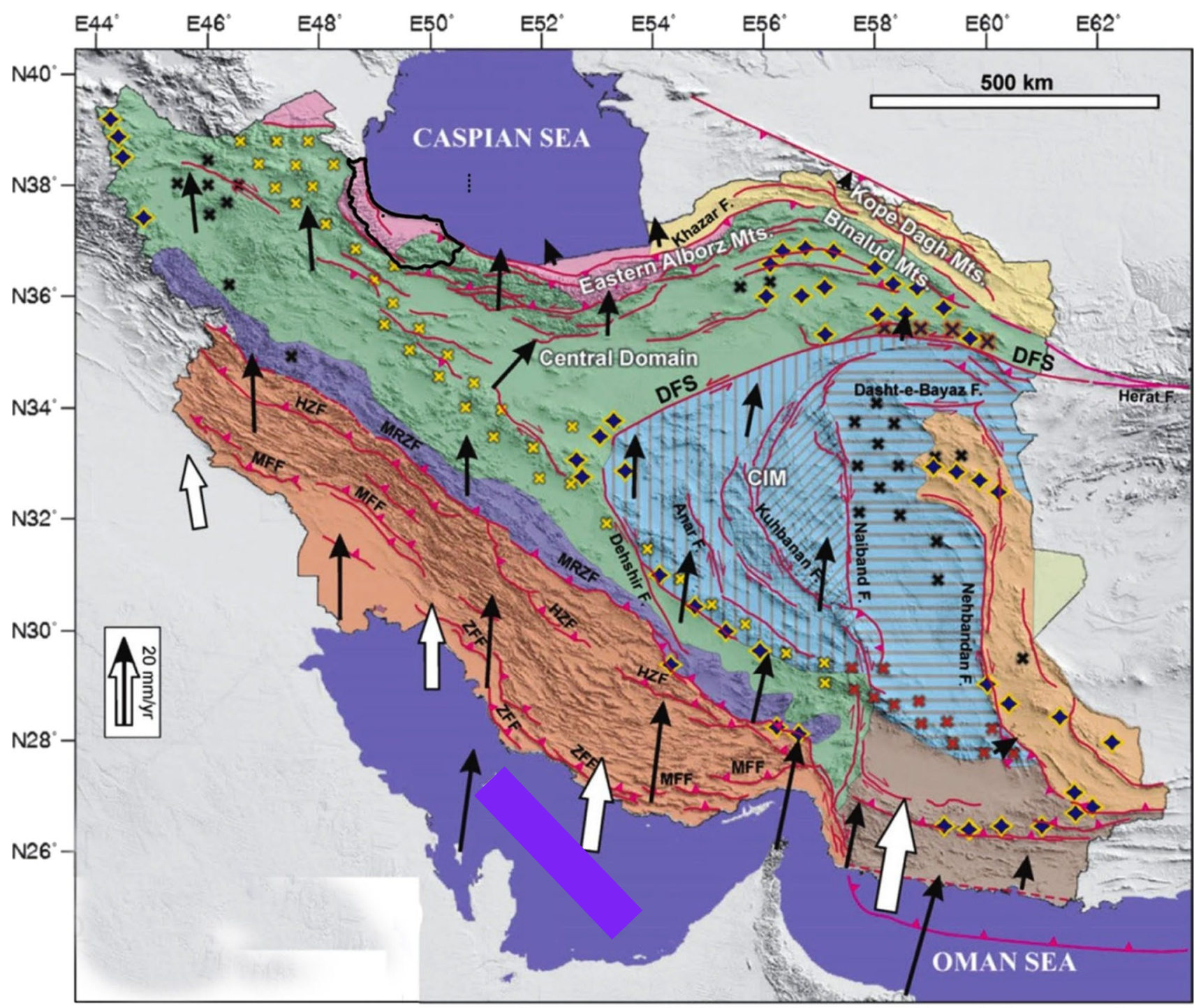

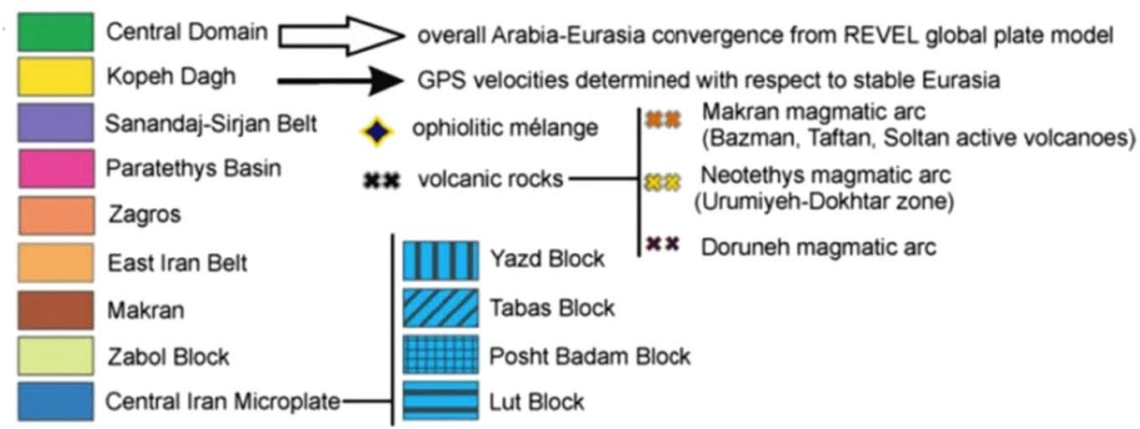

Fig. 1 Structural units of Iran (modified after Stocklin, 1968)

(Fig. 3E), Tirgan Formation (with lithology, marl, and shale lithology) (Fig. 3E), Sarcheshmeh Formation (with shale and marl lithology), lithologic marls and alluvial deposits. Tectonically, the basin has been affected by the Ardak fault, resulting in crushed zones and numerous fractures in the hard rocks of the area.

\section{Geomorphology and climatic settings of the Ardak area}

The Ardak study area is representative of conditions for the evolution of alluvial fans in semi-dry lands with a fluctuation in sediment supply and a long-term climate change. 
Recent climatic conditions of northeast Iran are much drier than during the Pleistocene and Lower Holocene (Walker and Fattahi, 2011). The climate of the study area is relatively semi-dry and mild. The mean annual precipitation is about $420 \mathrm{~mm}$ and the mean annual temperatures are $12.5^{\circ} \mathrm{C}$. The Ardak catchment area is located in Khorasan Razavi Province $80 \mathrm{~km}$ northwest of Mashhad city $\left(59^{\circ}\right.$ $30^{\prime} 51^{\prime \prime}-59^{\circ} 08^{\prime} 8^{\prime \prime}$ E, $36^{\circ} 43^{\prime} 14^{\prime \prime}-36^{\circ} 52^{\prime} 05^{\prime \prime} \mathrm{N}$ ) covering an area of $3350 \mathrm{~km} 2$ (Fig. 2). The highest point is around $2375 \mathrm{~m}$ asl, and is located in the northwest, part of the mountain area, while the lowest point is found in the southwest part at $1360 \mathrm{~m}$ asl, in the peneplain area (Fig. 3A). The ephemeral rivers system cut across several basin bounding faults and build large Quaternary alluvial fans (Ardak fan) in the southeastern part downstream. The Ardak fan covers an area of $256 \mathrm{~km}^{2}$. The rivers have an average runoff of $1460 \mathrm{~m}^{3}$ and run mostly during the winter period (October-March). Due to the high topographical and lithological properties, the main pattern of drainage is dendritic in the upstream section, while the middle sections are characterized by parallel streams with braided channels due to changing some parameters such as geological units and decreasing topography. The width of main rivers varies from $1-10 \mathrm{~m}$ to $100-250 \mathrm{~m}$ at upstream sections. Alternate bars in the braided streams are common (Fig. 3B). There are a lot of sunken meanders, as relicts of Pleistocene valley formation and tectonic uplifting. The general patterns of river channels determine the deposition of alternate bars, channel walls, and water flow. However, it should be mentioned that the type of channels is isolated with bed load as well as alternate bars and lateral movement. In some parts, river bending has changed the direction of alternate bars. The rate of flow and spread of flooding have significant effect on the size of flood plain sediments. Intensive flooding covers the flood plain with cobble- and gravel-sized sediments, while temporary and short-period flooding cover the flood plain with fine-grained sediments. Downstream, the valley slopes are low and the large floodplain has a width of up to $250 \mathrm{~m}$, whereas in the mountain area, the valley and its floodplain become narrower and averaging only $8 \mathrm{~m}$ in most sections. Small-scale arc-shaped alluvial fans are found downstream, when the mouth of tributaries enters into the main channel due to decreasing of the slope and energy level. The volume and expansion of fans depend on the amount of sediment supply, the width of branch and its slope. The Ardak catchment and basin is one of several in tramontane, fault-bounded areas within the northeast Iran (Arzani 2005, 2012). Ardak catchment is located in northeast of Iran, so it is one of the main basins of the Atrak River.
Fig. 2 Google earth image of the Ardak catchment area showing the rivers $\mathrm{A}, \mathrm{B}, \mathrm{C}$, and $\mathrm{D}$

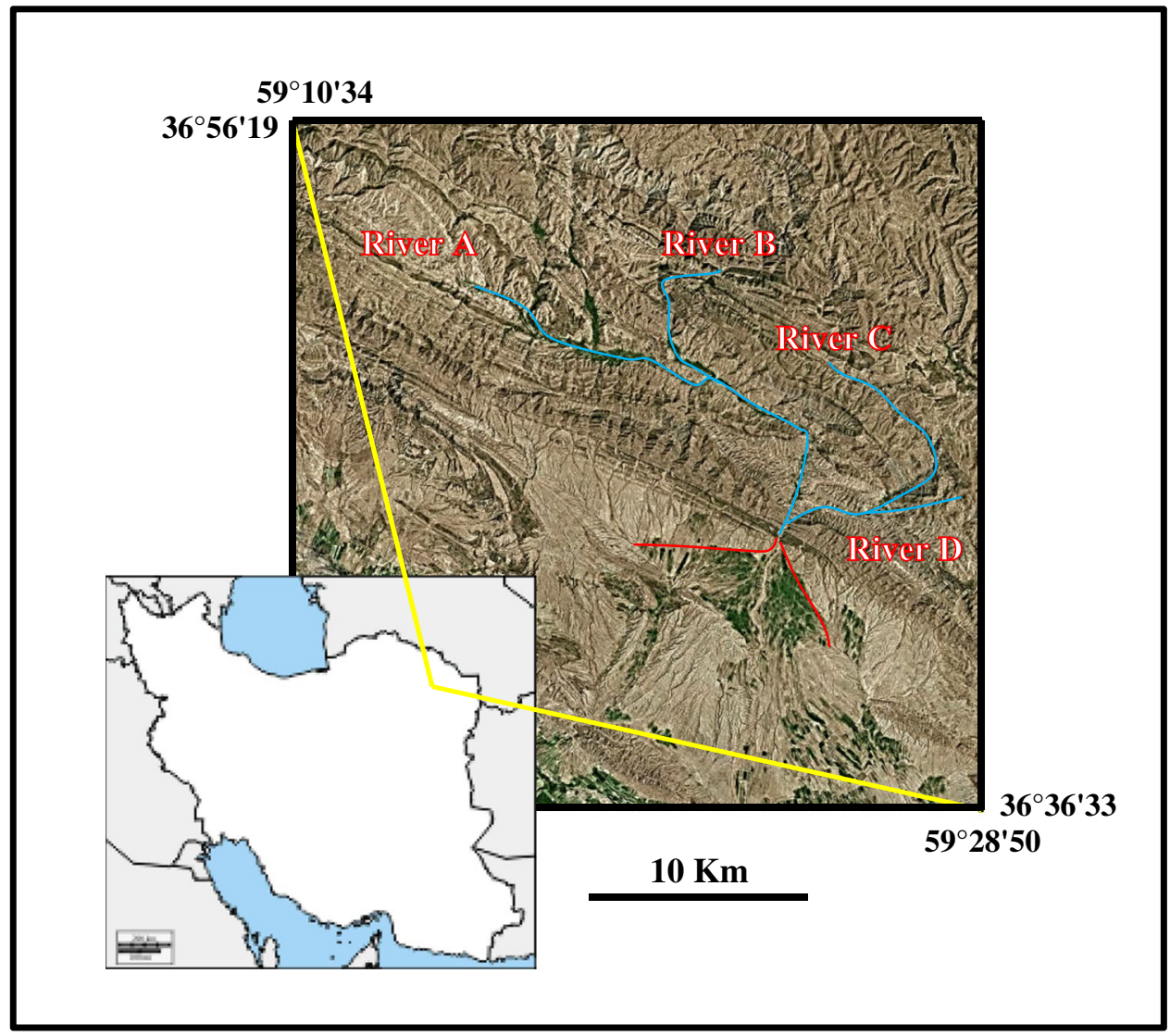


Four major stream channels (A, B, C, and D, Fig. 4A) are found within the catchment area. River (A) originated from Boghmech Mountains (Cretaceous limestone) which is located in western side of the basin, following NW-SE trends and discharge its sediment into the dam during seasonal flooding (Fig. 4A). The height variation of river (A) is shown in Figs. 5A. The slope of river A in upstream is higher than downstream, indicating steep slope walls in upstream. Toward downstream of river A, slope percentage decreases; however, the width of channel increases and flowing energy is reduced. Height decreases relatively gently. Lithology is relatively uniform along the main channel. Cretaceous limestone and the Jurassic sediments derived from erosion of the limestone are the main units along this river. River B originated from Amrudak Mountains which is located on the central side of the basin. The river follows $\mathrm{N}-\mathrm{S}$ to NW-SE trends and discharge its sediment into the dam (Fig. 4A). River B cuts through Cretaceous silisiclastic rocks and continued through Cretaceous and Jurassic carbonate units. Due to the steep slope of high lands, the slope percentage is more than downstream (Fig. 5B). River $\mathrm{C}$ originated from the Kakoli Mountains which is located in the northeastern side of basin, following NW-SE trends parallel to river $\mathrm{C}$ and discharge its sediment into the dam (Fig. 4A). Height and slope percentage are almost uniformly reducing toward downstream. This river is characterized by steep walls and increasing its width and decreasing its slope downstream (Fig. 5C). The river cuts through Jurassic limestone upstream and along the main channel, and Cretaceous silisiclastic units in middle parts, and Quaternary sediments in the lower parts. River D originates from the Kalateh Mountains in the southeastern side of basin, following NE-SW trends. It crosses Jurassic limestone and Eocene intrusive and discharge its sediment into the dam during seasonal flooding (Fig. 4A). Height and slope percent values are almost uniform along main channel (Fig. 5D). The slope of this river is less than the other rivers (Fig. 4C).

\section{Methodology}

Fifty-seven sediment samples were collected at different sites along four major main-stream channels (A, B, C, and D; Fig. 4A) and exposed bars at 500-1000 $\mathrm{m}^{2}$ intervals (lateral, mid-channel, and point bars). These sites were selected with reference the progressive increase in drainage area, tributary inputs, current river regime, and lithological variability of the catchment area. For the grain-size analysis, the samples were sun-dried and then disaggregated with hands. Cobble-, pebble-, and gravel-bed (surface bed) material were sampled using a modified Wolman (1954) pebble counts sampling method. Surficial samples were collected from surface to the depth of $30 \mathrm{~cm}$ along the four rivers. The samples were subsequently weighed and sieved for particle-size distribution. Cumulative curves were plotted followed by determination of statistical parameters/or main granulometric parameters such as mean, median, sorting, skewness, and kurtosis based on the concept of Folk and Ward (1957) and Folk (1980). Lithofacies were identified in the field using parameters, such as lithology, grain-size, color, sedimentary structures, geometry of lithologic units, and their mutual association following the classification scheme of Walker and Cant (1984) and Miall (1996). Thirty-four representative fresh samples were selected for study using macroscopic features. The environmental reconstruction was based on the description and interpretation of lithofacies and lithofacies associations.

\section{Sedimentology}

\section{Grain size and statistical parameters}

Grain size analysis and statistical and textural indices of the collected samples from the four rivers are given in Tables 1 , 2 and displayed in Figs. 6, 7, 8, and 9. The main source of alluvial channels sediments in the study area is Cretaceous and Jurassic carbonate, Cretaceous sandstone, and the associated Quaternary materials. A variety of clasts with different sedimentary origins along with different textural parameters, namely, angularity and sphericity have been found.

Sedimentary particles through the main channel of river (A) consist of homogenous lithology, mainly Mozduran2 (dolomite grains $~ 59.1 \%$ ) and Tirgan (carbonate grain $28.8 \%$ ) (Table 3). Grain size analysis of 13 samples along river A is shown in Fig. 6A. The percentages of gravel, sand, and mud are between 74-96, 2-22, and 1-9, respectively. Gravel-sized grains experience a downstream decreasing trend, while sand and mud grains experience a downstream increasing trend (the difference between mean and median increases) (Figs. 6B and C). Because of entering tributaries and changing the percentage of slope, discontinuities in graphs are observed. The discontinuities show a decreasing trend in mode and mean values (phi). Due to high energy level and sediment emerging in river A, tiny minority amount of mud can be seen. The homogenous lithology, seasonal flooding, and joining different tributaries into the main channel boosting the carrying potential of river $\mathrm{D}$ are the main reason for pebbles' frequency. Sorting has been ranged very poorly. Due to requirement of high energy carrying grains in a short time and sudden reduction in flowing velocity, both coarse and fine grains deposit simultaneously; therefore, gravel sediments are poorly sorted. Entering tributaries to the main channel change the grain size, sorting, and discontinuity in the graphs, mainly downstream. However, homogenous lithology and flowing continuity would 

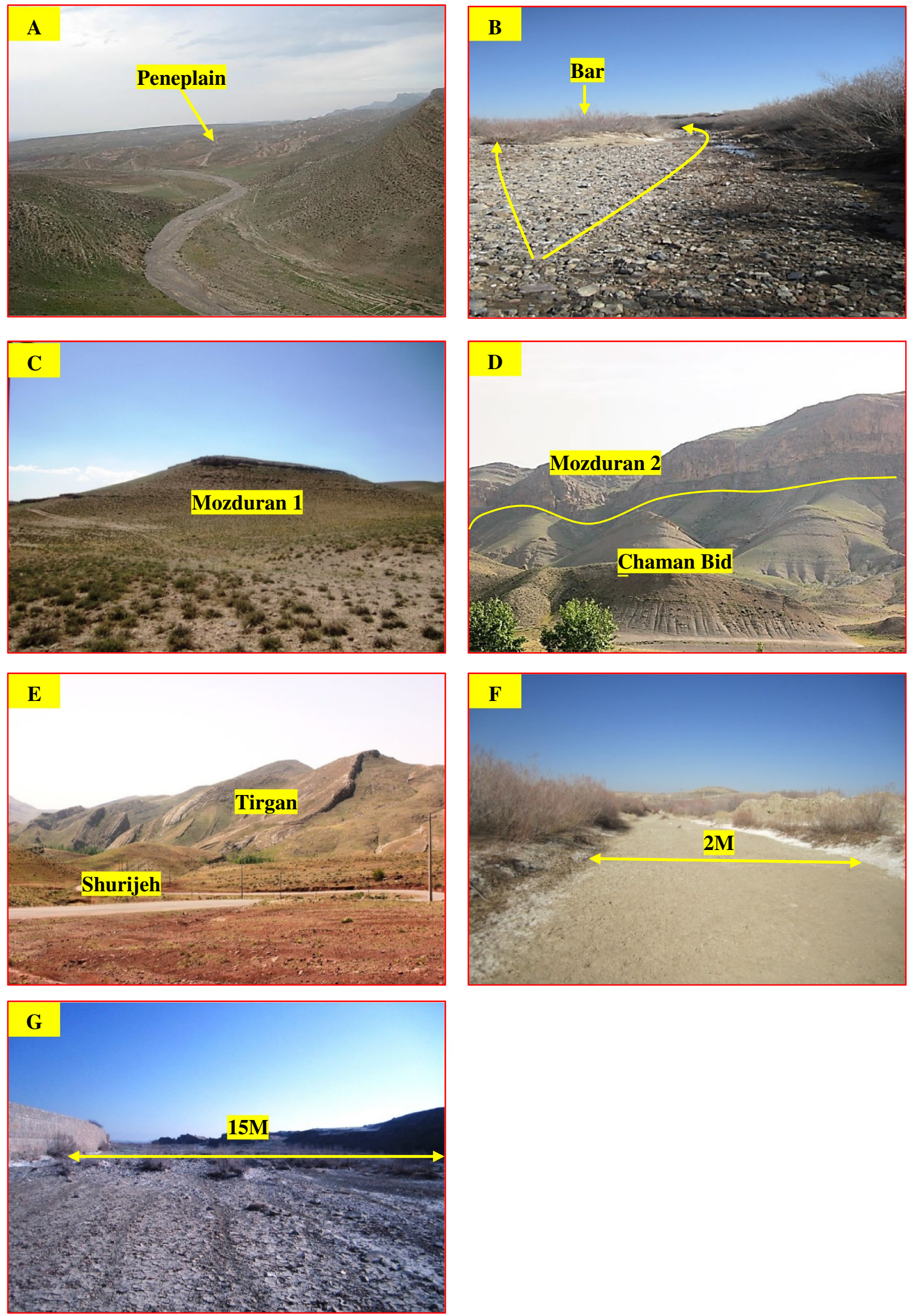
4Fig. 3 Geomorphologic and geologic evidences of the catchment area. A The peneplain form in the river, B alternate bar, C Mozduran1 Formation in the catchment, D Mozduran2 and Chaman bid Formation in the catchment, $\mathbf{E}$ Tirgan and Surijeh Formation in the catchment, $\mathbf{F}$ V-shaped vally and width of channel $\mathbf{C}$ in upstream, $\mathbf{F}$ width of channel in downstream increase sorting downstream (Fig. 6C). Skewness has been used for interpreting sedimentary environment and processes affecting transportation. Skewness of river A varies strongly fine (very positive), which may indicate that continuity of flowing in the main channel may result in increasing the
Fig. 4 Simplified maps showing the A sampling sites, B lithological units, and $\mathbf{C}$ geomorphological units Ardak catchment area
A

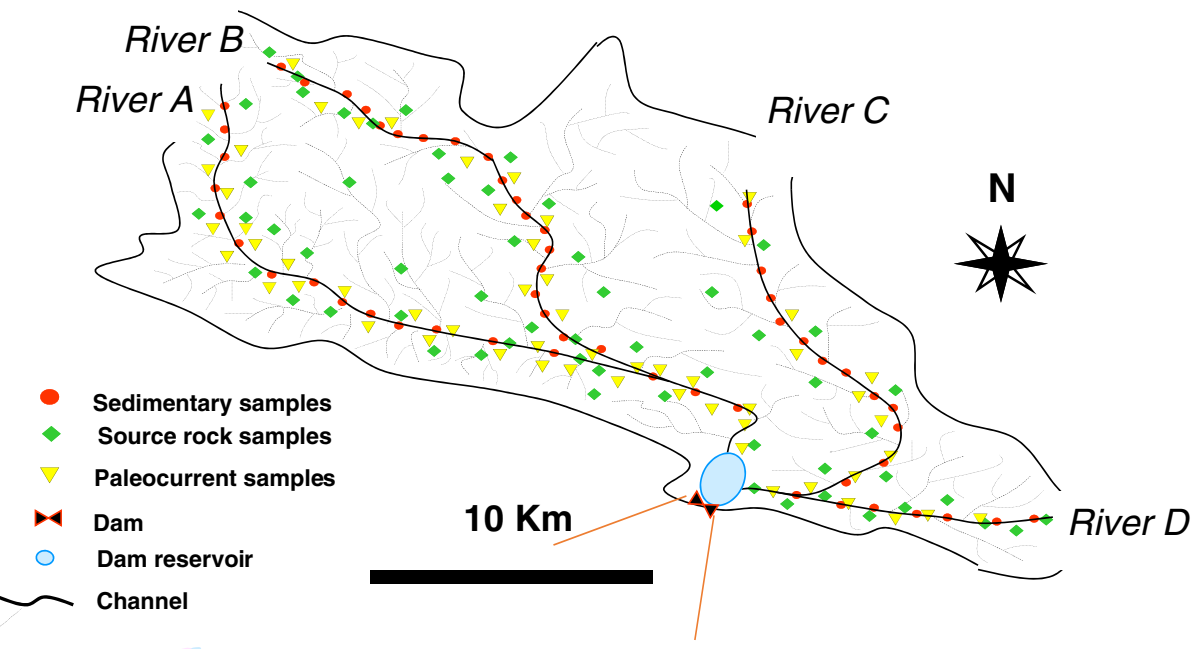

B

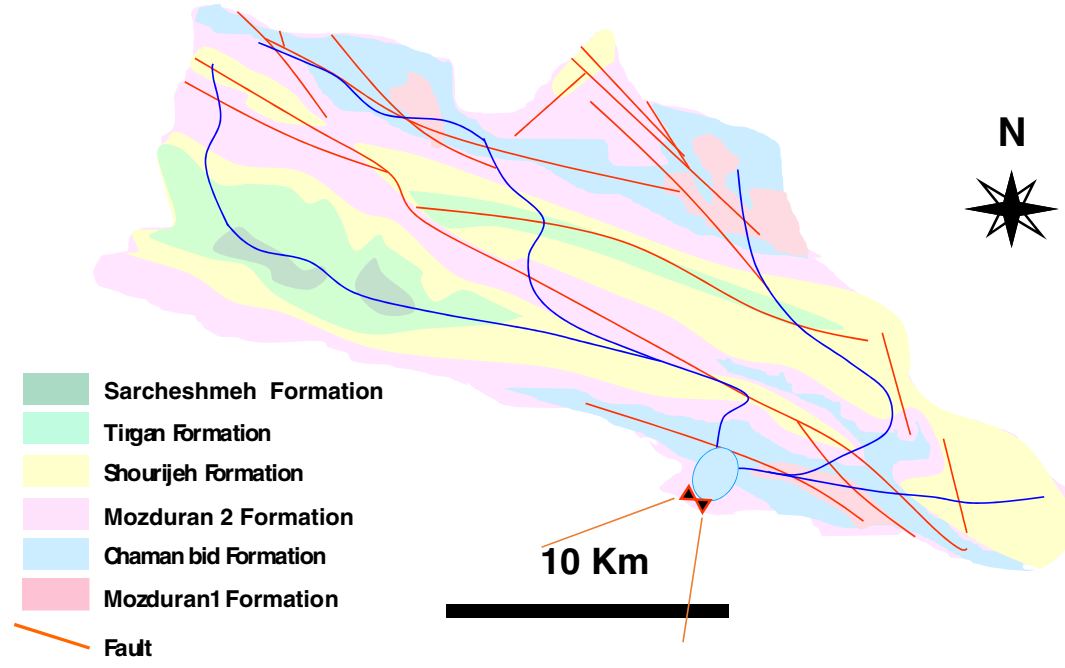

C

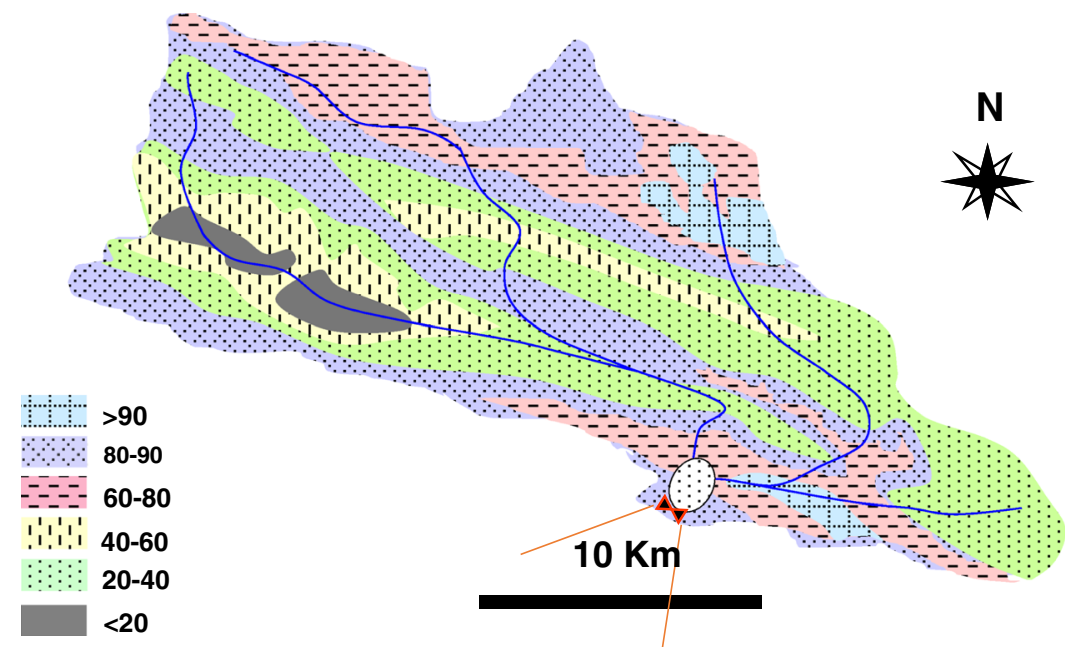



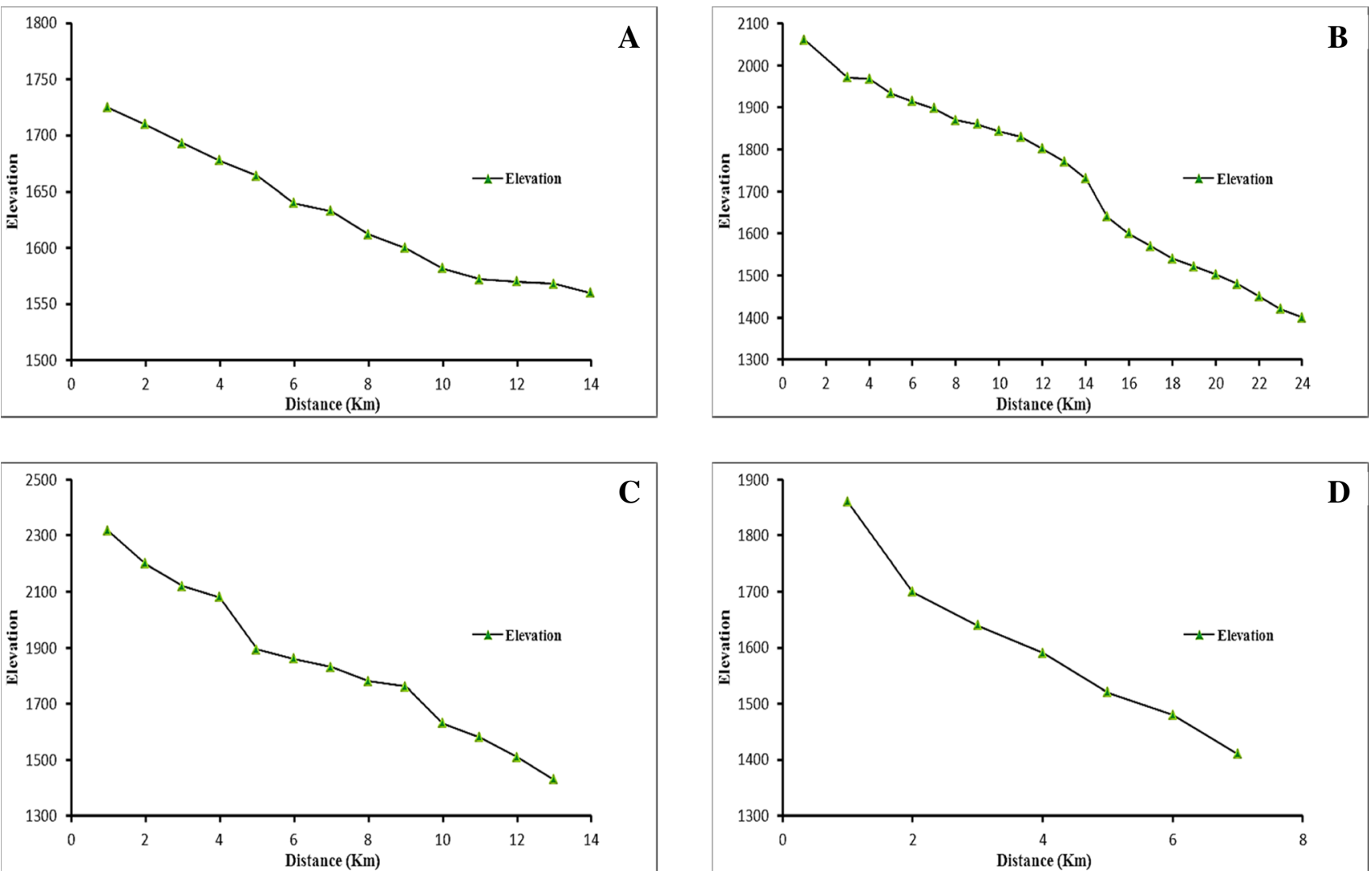

C

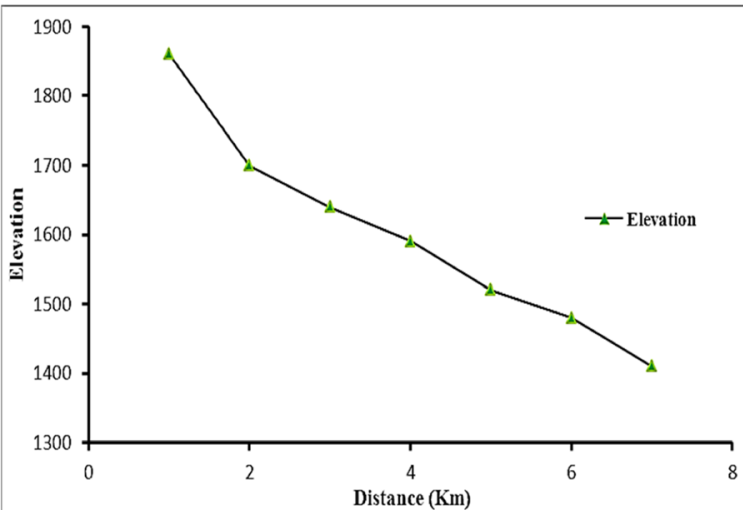

D

Fig. 5 Downstream changes vs elevation in river A to D. A River A, B river B, C river C, D river D

volume of fine grains. Kurtosis values in river A samples show a variety of dispersion with different shapes like platymeso to leptokurtic toward downstream. The ratio of gravel/ sand in rivers decreases downstream (Fig. 6D).

River B cut down highly fractured and faulted Jurassic dolomite units, mainly in the upstream parts, where four different types of clasts were recognized; the most common are Muzduran2 (average 64.5\%), Tirgan (20\%), Chaman Bid (7.6\%), and Shurijeh fragments (7.2\%) (Fig. 7A, Table 3). Grain size analysis of 24 samples along river $\mathrm{C}$ is shown in Fig. 7A. The percentages of gravel, sand, and mud are more variable in comparison to river $\mathrm{A}$, and range between $\sim 60-945, \sim 3-36$, and 2-9, respectively. There is no general trend of decreasing or increasing grain size up- or
Table. 1. Grain size analysis in rivers $\mathrm{A}$ to $\mathrm{D}$

\begin{tabular}{lllllll}
\hline Rivers & & $\% G$ & $\% S$ & $\% M$ & $\% G / S$ & Elevation \\
\hline A & Min & 74 & 2 & 1 & 3.3 & 1560 \\
& Max & 96 & 22 & 9 & 47.5 & 1725 \\
& Mean & 84.1 & 12.1 & 4.1 & 13.6 & 1630 \\
B & Min & 60 & 3 & 2 & 1.6 & 400 \\
& Max & 95 & 36 & 9 & 31.6 & 2060 \\
& Mean & 81.2 & 13.4 & 4.8 & 9.9 & 1721 \\
C & Min & 75 & 4 & 1 & 3.7 & 1430 \\
& Max & 94 & 20 & 6 & 23.5 & 2317 \\
& Mean & 83.2 & 12.8 & 4 & 9.4 & 1849 \\
D & Min & 75 & 7 & 1 & 3.7 & 1410 \\
& Max & 92 & 20 & 6 & 13.1 & 1860 \\
& Mean & 85 & 11.2 & 2.7 & 9.2 & 1607 \\
\hline
\end{tabular}

$\% G$ gravel, $\% S$ sand, $\% M$ mud 
Table. 2. Statistical and textural indices in rivers $\mathrm{A}$ to $\mathrm{D}$

\begin{tabular}{|c|c|c|c|c|c|c|}
\hline Rivers & Mean & & Median & Sorting & Kurtosis & Skewnes \\
\hline \multirow[t]{3}{*}{ A } & Min & -3 & -2.9 & 1.3 & 0.8 & 0.3 \\
\hline & Max & -1.6 & -1.5 & 1.9 & 1.5 & 0.9 \\
\hline & Mean & -2.4 & -2.3 & 1.6 & 1.1 & 0.4 \\
\hline \multirow[t]{3}{*}{ B } & Min & -3.1 & -2.7 & 1.4 & 0.7 & 0.2 \\
\hline & Max & -0.8 & -0.8 & 2.1 & 1.2 & 0.9 \\
\hline & Mean & -2.1 & -1.8 & 1.6 & 0.9 & 0.4 \\
\hline \multirow[t]{3}{*}{$\mathrm{C}$} & Min & -3.5 & -3.3 & 1 & 0.5 & 0.4 \\
\hline & Max & -0.5 & -0.5 & 2.8 & 1.2 & 0.7 \\
\hline & Mean & -1.7 & -1.5 & 1.9 & 0.9 & 0.5 \\
\hline \multirow[t]{3}{*}{ D } & Min & -3.6 & -3.8 & 1.5 & 0.9 & 0 \\
\hline & Max & -1.2 & -1.6 & 2.5 & 1.3 & 0.9 \\
\hline & Mean & -2.2 & -2.5 & 2.1 & 1.1 & 0.5 \\
\hline
\end{tabular}

downstream. The $\%$ of gravel upstream is 80 , whereas it is $90 \%$ downstream near the dam. Unlike gravels, sands undergo considerable changes downstream. Sedimentary discontinuity is indicated by a sudden decrease in slope graph due to sudden decrease in slope and joining of river A to river B. The low percent of mud size is more likely attributed to downslope washout by surface running waters. Therefore, the amount of mud in these deposits is negligible (Fig. 7B). Mean and mode values decrease with decreasing slope and energy and show discontinuities of decreasing trend due to change in slope. Sorting varies from very poorly to poor due to continuous river flow and deposition
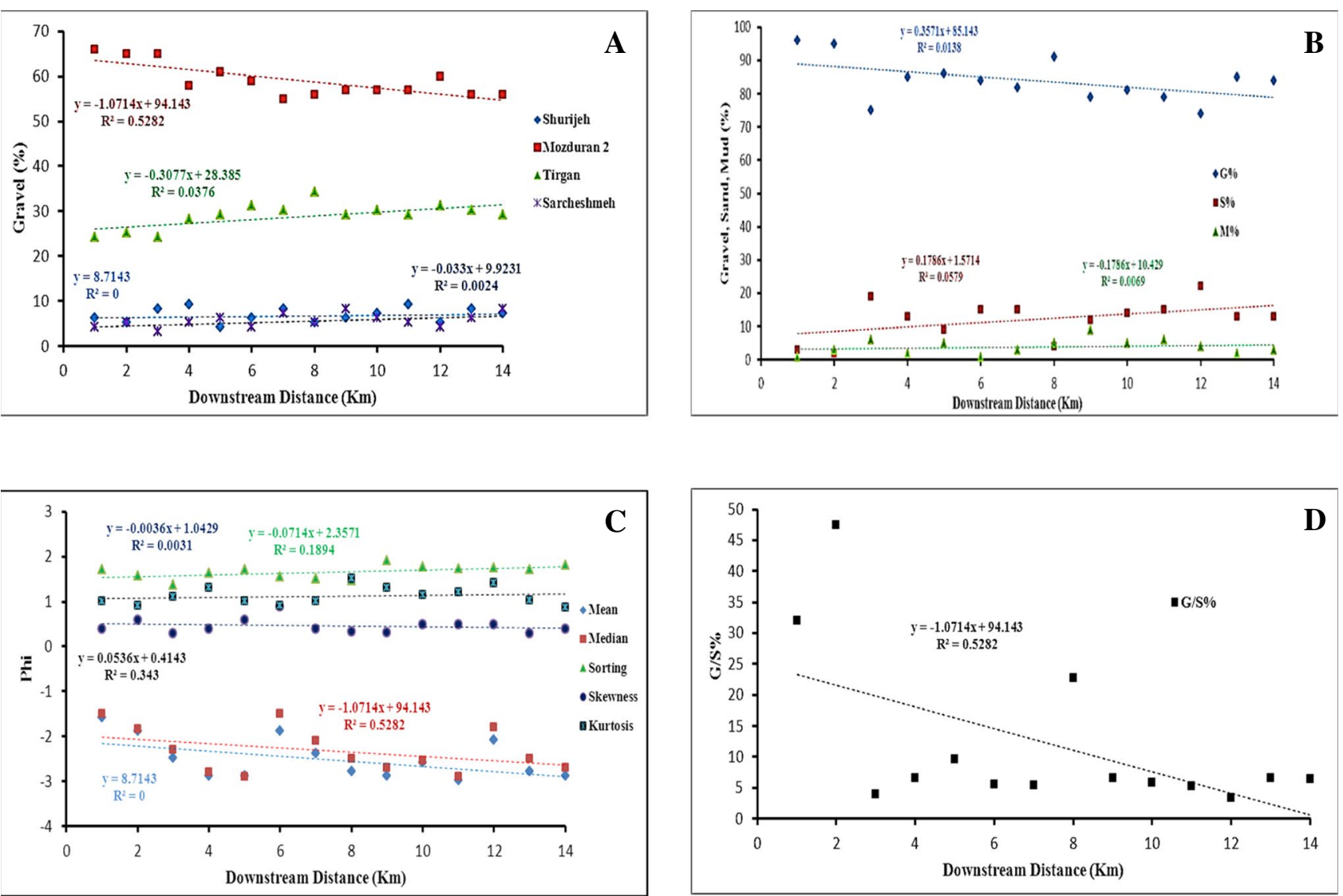

Fig. 6 Downstream changes vs A distribution of gravels, B percentage of three main grains, C textural parameters, D $G / S$ ratio, of river A 
of similar grains. Skewness and kurtosis show wide fluctuation along the channel and are strongly fine to fine and platy- to mesokurtic, respectively (Fig. 7C). Figure 7D shows the ratio of gravel/sand against downstream distance. Decreasing fine-grained particles downstream shows increasing gravel/sand ratio. The amount of gravel at the sampling is higher than others. A sudden increase in the ratio of gravel/sand in samples is due to a dramatic increasing of Jurassic dolomite fragments along the steep slope in upstream of channel B. The upstream lithology of river $\mathrm{C}$ is similar to that of river $\mathrm{B}$, which is mostly composed of dolomite rocks (Mozduran2) and sporadic Jurassic limestone particles. Four types of grain are found, namely, dolomite fragments (Mozduran2 52.53\%) and carbonate fragments (Mozduran1 26.23\%) (Table 3). The trend of sedimentary particles has fluctuated along main channel (Fig. 8A). River $\mathrm{C}$ is characterized by a downstream increasing gravel size ( $75 \%$ upstream to $91 \%$ downstream) and decreasing sand size (20\% upstream to 7\% downstream) (Fig. 8B). Weight percent values of mud-sized fluctuate between 1 and $6 \%$. Slight fluctuation is observed due to changes in lithology, geomorphological conditions and entering tributaries along the river. The mean of all samples is more than median
(Table 2 and Fig. 8C). Discontinuities in the graphs of mean and median are mainly due to reduction in flow energy and slope downstream. The differences of width of channel $\mathrm{C}$ from up to downstream are shown in Figs. 3F and G. Increasing coarse grain gravel-sized particles along with decreasing of sand-sized grains through this river resulted in increasing the standard deviation in the river sediments and consequently reduces sorting values (Fig. 8C). Skewness shows a decreasing trend downstream (Fig. 8C). The samples have experienced a very positive trend downstream, and the kurtosis values are correlated with sorting. The ratio of gravel/sand shows an increasing trend (Fig. 8D and Table 1), which has a direct relation to clasts coarsening River $\mathrm{C}$ cut down dolomite rocks in its middle-upper parts and limestone lithologies at midstream. The average frequency of dolomite and carbonate fragments is $89.8 \%$ and $8.7 \%$, respectively (Fig. 9A). Grain size and weight percent values of the main group of sediments (gravel, sand, and mud) along channel D are shown in Fig. 9B. Toward downstream, gravel values vary from 88 to $80 \%$, whereas sand values vary from 10 to $14 \%$. Weight percent of muds fluctuates between 2 and 4\% (Fig. 9B). In general, gravel-, sand-, and mud-sized particles show fluctuation in their
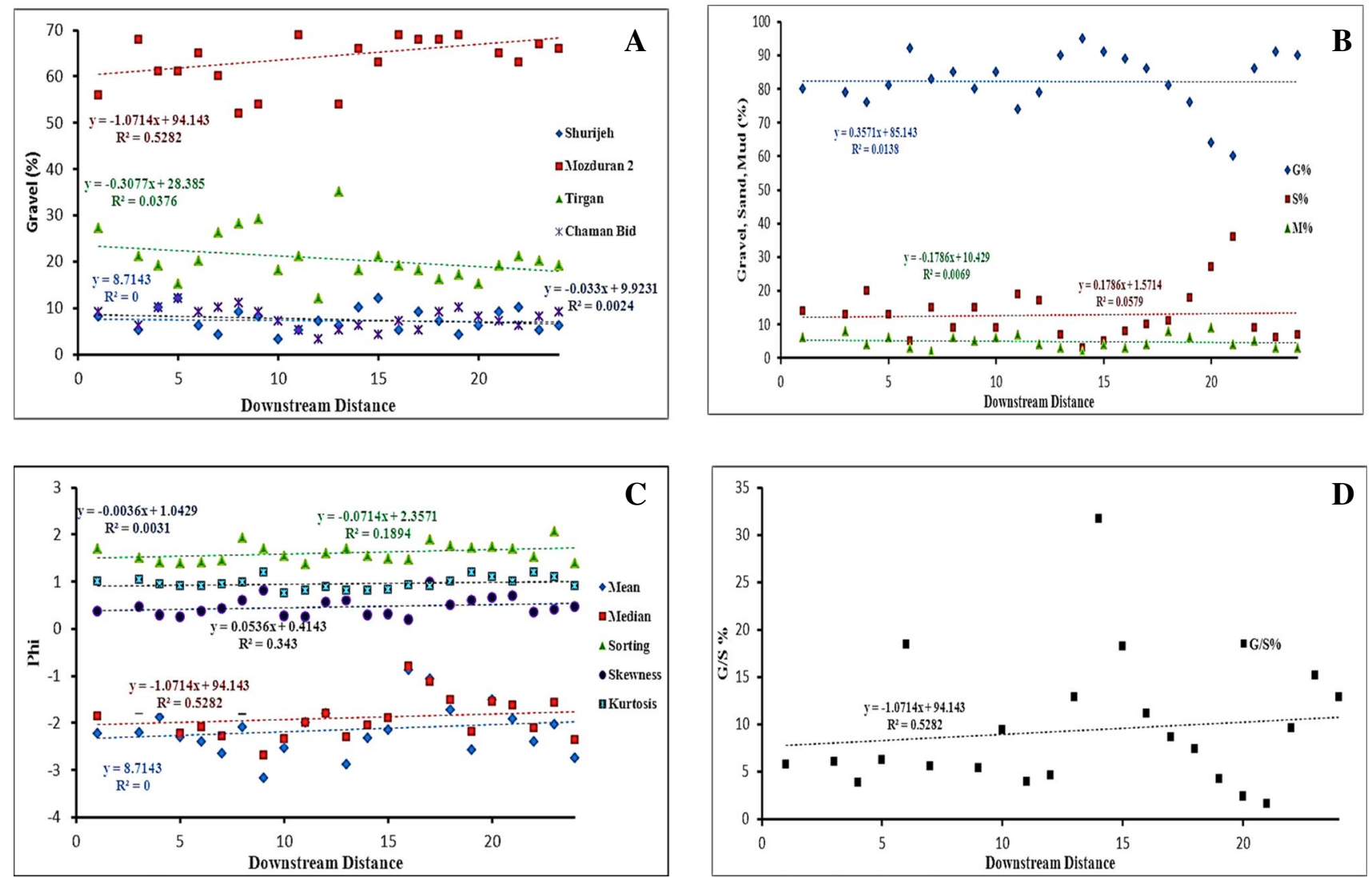

Fig. 7 Downstream changes vs A distribution of gravels, B percentage of three main grains, C textural parameters, D $G / S$ ratio, of river B 
values due to lithological variations, geomorphological conditions, and slope changing, entering tributaries. Median and mean graphs show at river D (Fig. 9C). Grains are from poorly to badly sorted. Increasing in sand- and mud-sized particles toward downstream along with decreasing coarse gravel particles are the main reasons of decreasing of sorting (Fig. 9C). The general trend of decreasing skewness (very positive to symmetric) toward downstream can be due to decreasing energy and increasing of particles in size of sand and mud. Kurtosis distribution in this channel is lower than in the other rivers. The gravel/sand ratio in river $\mathrm{A}$ is shown Fig. 9D.

\section{Facies and structural elements}

The sediments of the Ardak basin were studied for the sediments recorded in vertical sections at various localities, and facies analysis was made along the four river channels mainly at those sites where seasonal flooding has not terminated the sequences. Facies analysis was performed using Miall's (1996) lithofacies classification scheme. According to this scheme, eight lithofacies were identified (Fig. 10), while three main facies associations were identified:
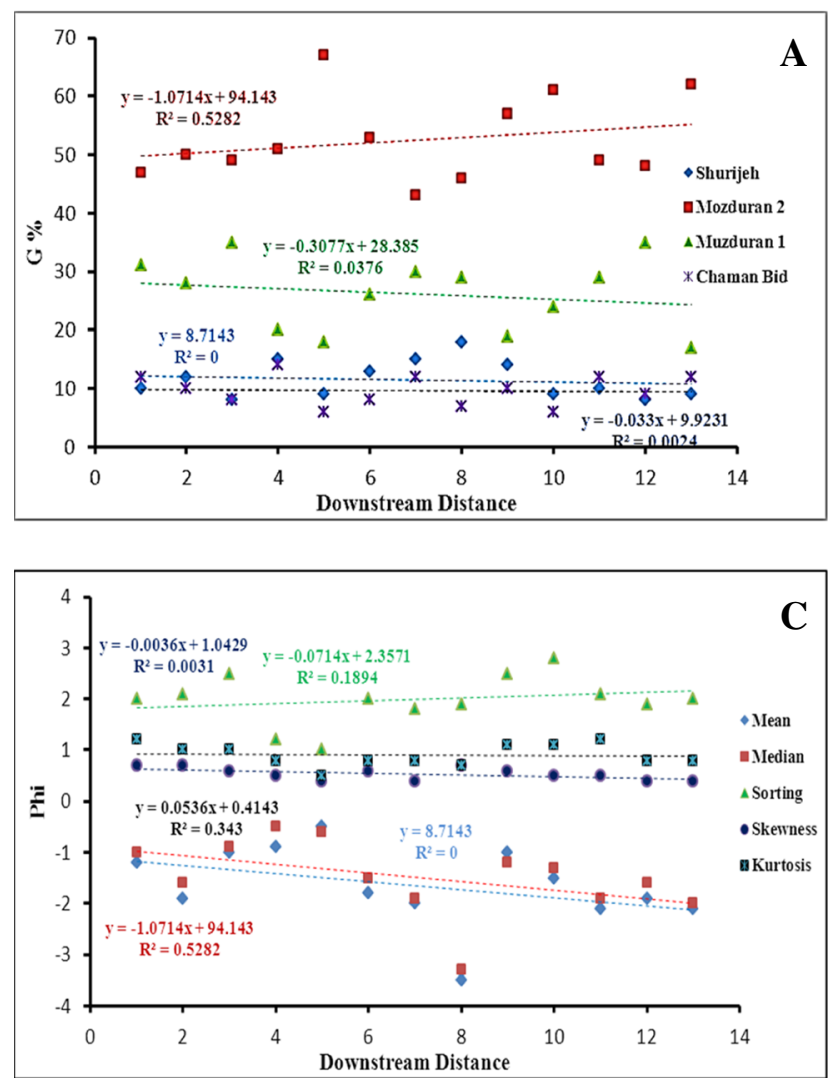

a. Gravelly-dominated facies association

The gravelly dominated facies association contains gravels that are matrix to clast supported with various clast sizes and nature (dolomite, limestone, quartz, and clay). The clast sizes vary between pebble and cobble and sometime boulder. Massive matrix-supported gravel faices $(\mathrm{Gmm})$ is $55-90 \mathrm{~cm}$ thick and consists of angular, poorly sorted clasts that are supported with poorly sorted sand-silt matrix. This facies is associated locally with muddy matrix-supported gravel and $10-50 \mathrm{~cm}$ thick, massive clast-supported gravel (Gcm facies) which contains subangular to subrounded, poorly sorted imbricated clast. The basal boundary of the $\mathrm{Gcm}$ facies is erosional and sharp in some cases (Fig. 11A). These conditions indicate turbulent flow and high-energy process. The existence of clasts in range of boulders with muddy and sandy matrix in Gmm and Gcm facies in the middle and upper parts of the channel walls is mainly due to tectonic factor (e.g., abundant faulting), and due to the high slope in the study areas. The massive graded gravel facies (Gmg) show normal grading at basal parts and inverse grading at top of sequences. Inverse grading of this facies is associated with a gradual increasing in energy and clast size. The Gmg facies has a thickness
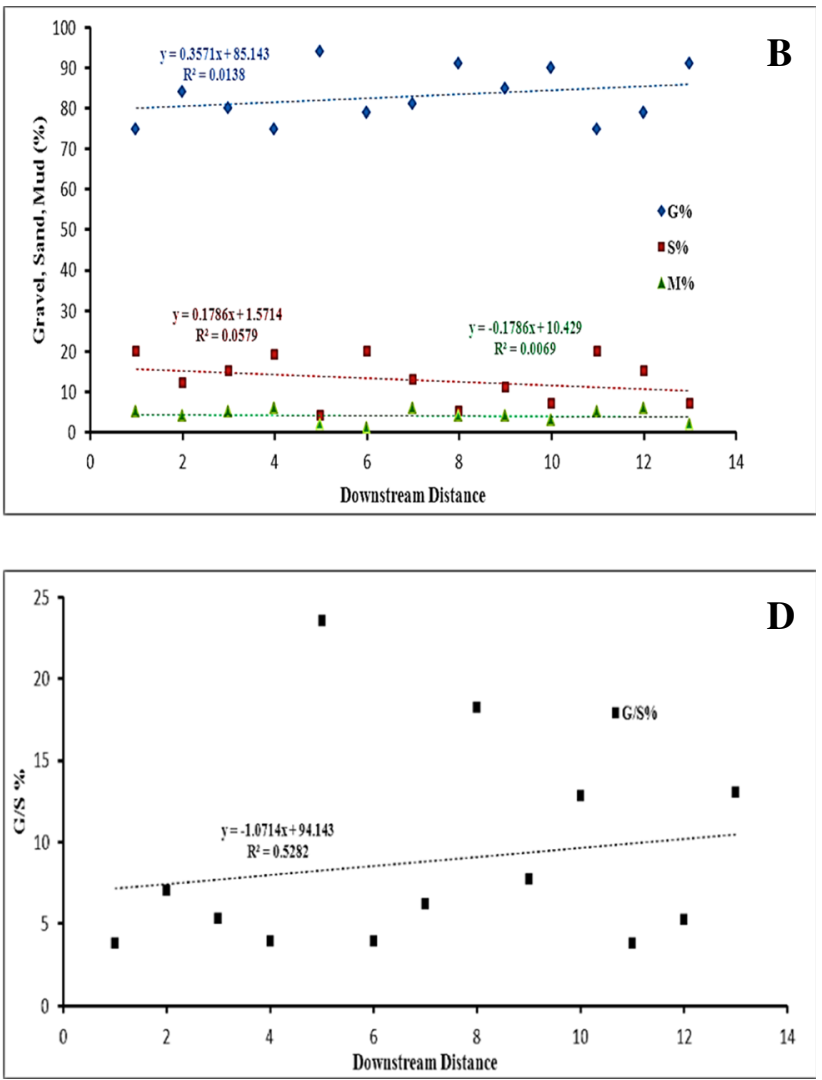

Fig. 8 Downstream changes vs A distribution of gravels, B percentage of three main grains, $\mathbf{C}$ textural parameters, D $G / S$ ratio, of river C 
of $40-45 \mathrm{~cm}$ and usually formed in the upper parts of the channel wall (Fig. 11C). The size of coarser clasts at lower part is $33 \mathrm{~cm}$ and $3 \mathrm{~cm}$ for finer clasts at upper part. This facies is considered a channel fill. Limestone clasts are poorly sorted, angular to subangular because of their location near the source, while dolomite clasts are poorly to medium sorted, subangular to subrounded due to long distance of transport form their source.

b. Sandy-dominated facies associations

This association is composed of fine to medium and coarse to very coarse-grained sandstones, containing pebble- and granule-sized sands, and rare reworked cobblesized particles. Maximum size of the pebbles is $1 \mathrm{~cm}$. Facies Sm (massive sand) is $32 \mathrm{~cm}$ thick, occurs mainly in channel A. It consists of massive fine to very coarse, sometimes pebbly sandstone. The average size of particles varies between 0.5 and $1.5 \mathrm{~mm}$ (medium to very coarse). This facies is deposited under lower energy condition (Fig. 11A). Intergrain pores are filled with a clayey matrix, giving the rock a grayish color. Scarce amounts of medium sorted gravels intercalations may indicate a slight change in energy during deposition. Facies Sh (horizontally bedded sand) contains subangular, fine to medium sand and gravel with horizontal laminations consisting of $15-30 \mathrm{~cm}$ thick layers and ranges in color from pale brown to buff (Fig. 11D). It shows normal grading, often turning into massive mudstone (facies Fm and Fr) and fining upward at the top of the channel walls. The grain size range varies from 0.2 to $0.8 \mathrm{~mm}$. Facies Sh shows normal grading, often turning into massive mudstone (facies Fm) at the top of the study channels. Facies Sp (planar cross-bedded sand) consists of fine to very course (0.2-1.2 mm), medium sorted, angular to subangular, sometimes pebbly sandstone with planar cross-bedding and normal gradation (Fig. 11D). This facies is yellowreddish in color and ranges in thickness from 15 to $55 \mathrm{~cm}$. The levels of pebbly sandstone are concentrated at the lower parts and show rapid grading to finer and wellselected sandstone near the top of the channels. Laterally Sh faces can be intercalated with facies Gmg.

c. Fine grain dominated facies associations

Facies Fm (massive mud) is characterized by laminated grey mud and silts, including $5 \mathrm{~mm}$ to $100 \mathrm{~cm}$ thick layers (Fig. 11D). The millimeter levels of this facies are associated with the $\mathrm{Sm}$ and $\mathrm{Sh}$ facies at the top of the fining-upward sequences. This facies is formed under sus-
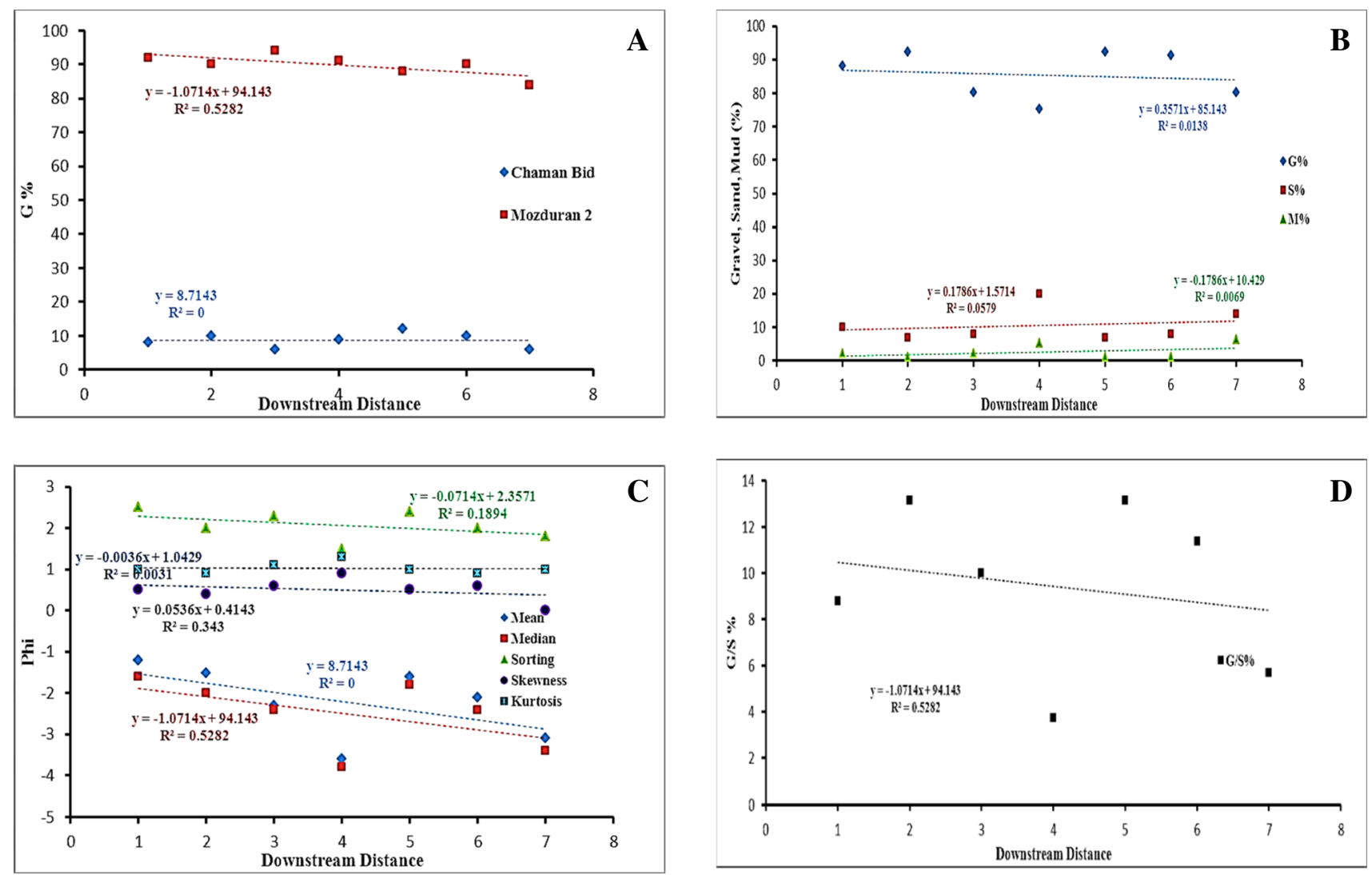

Fig. 9 Downstream changes vs A distribution of gravels, B percentage of three main grains, C textural parameters, D $G / S$ ratio, of river D 
Table. 3. Percentage of formations per sediment sample in rivers $\mathrm{A}$ to $\mathrm{D}$

\begin{tabular}{llllllll}
\hline Rivers & & $\% \mathrm{Mz}_{1}$ & $\% \mathrm{Ch}$ & $\% \mathrm{Mz}_{2}$ & $\% \mathrm{Sh}$ & $\% \mathrm{Tr}$ & $\% \mathrm{Sr}$ \\
\hline A & Min & - & - & 55 & 4 & 24 & 3 \\
& Max & - & - & 66 & 9 & 34 & 8 \\
& Mean & - & - & 59.3 & 6.6 & 28.8 & 5.4 \\
B & Min & - & 3 & 42 & 3 & 12 & - \\
& Max & - & 12 & 78 & 12 & 38 & - \\
& Mean & - & 7.6 & 64.6 & 7.2 & 20.8 & - \\
C & Min & 17 & 6 & 43 & 8 & - & - \\
& Max & 35 & 14 & 67 & 18 & - & - \\
& Mean & 26.2 & 9.7 & 53.8 & 11.8 & - & - \\
D & Min & - & 6 & 84 & - & - & - \\
& Max & - & 12 & 94 & - & - & - \\
& Mean & - & 8.7 & 89.6 & - & - & \\
\hline
\end{tabular}

$M z_{1}$ Mozduran Formation, $C h$ Chamanbid Formation, $M z_{2}$ Mozduran Formation, Sh Shorijeh Formation, $\operatorname{Tr}$ Tirgan Formation, $\mathrm{Sr}$ Sarcheshmeh Formation pension load in flood plain and/or as a mud drope covers top of sandy bars inside rivers where it can be seen with a minor thickness. Facies Fr (root bed) consists of $5-25 \mathrm{~cm}$ plant roots and occurs at the top of all channel walls (Fig. 11D).

\section{Palaeocurrent analysis}

Palaeocurrent directions were obtained from unidirectional sedimentary structures such as cross-stratification, parting lineation and imbrication. Dominant palaeocurrent direction in the study rivers is towards south-southeast indicating that the cliff faces are oriented roughly vertically to the paleoflow (Fig. 12). Sediments were delivered to the study area from both north and minor south high lands.

\section{Discussion}

Active tectonics controls accommodation space and location of the fan while passive tectonics can control the configuration of the catchment drainage network and its bedrock geology (Quigley et al., 2007; Salcher et al., 2010). Harvey et al. (2005) pointed to an increased recognition that tectonics tends to control fan location, while climate tends to control alluvial-fan sequences.

Climate controls sediment supply/water ratios and as the result distribution of different deposits, as well as aggradation or degradation on channel surface (Bull, 1991; Weissmann et al., 2002; Eppes and McFadden, 2008; Clarke et al., 2010; Waters et al., 2010). Sediment supply, which is a key factor and a dominant driver behind alluvial-fan formation, is controlled by catchment lithology (Leece, 1991; Levson and Rutter, 2000; Hartley et al., 2005; Wagreich and Strauss, 2005; Kanhaiya, et al., 2017; Kumar et al., 2019). The Ardak
Fig. 10 Histogram diagrams showing distribution of average composition of different lithofacies.in all samples

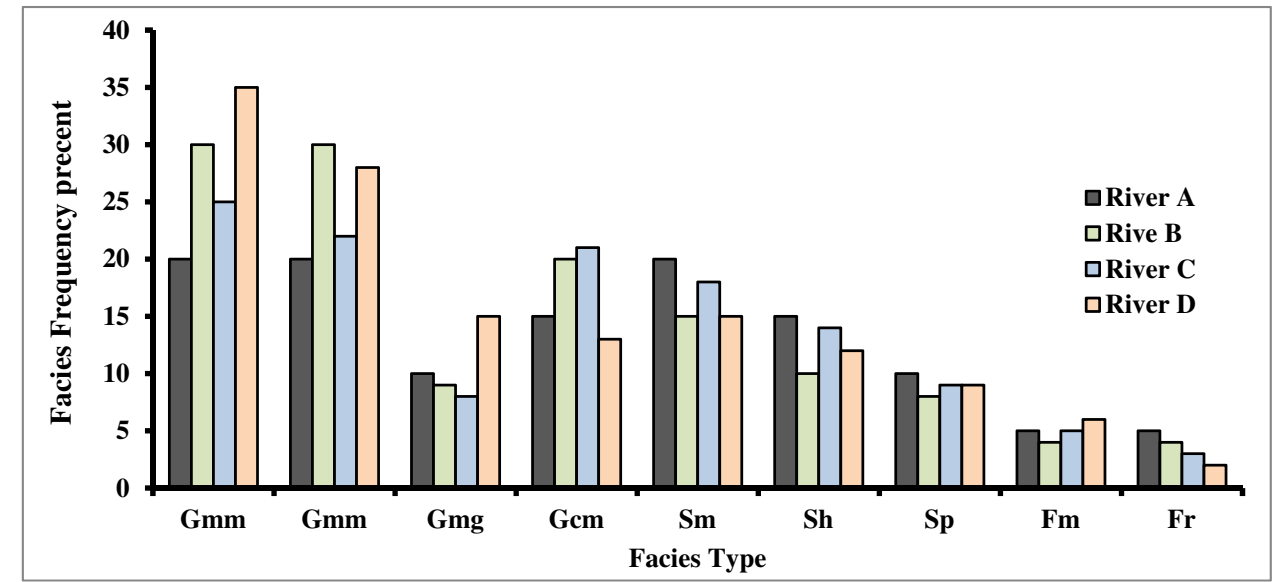



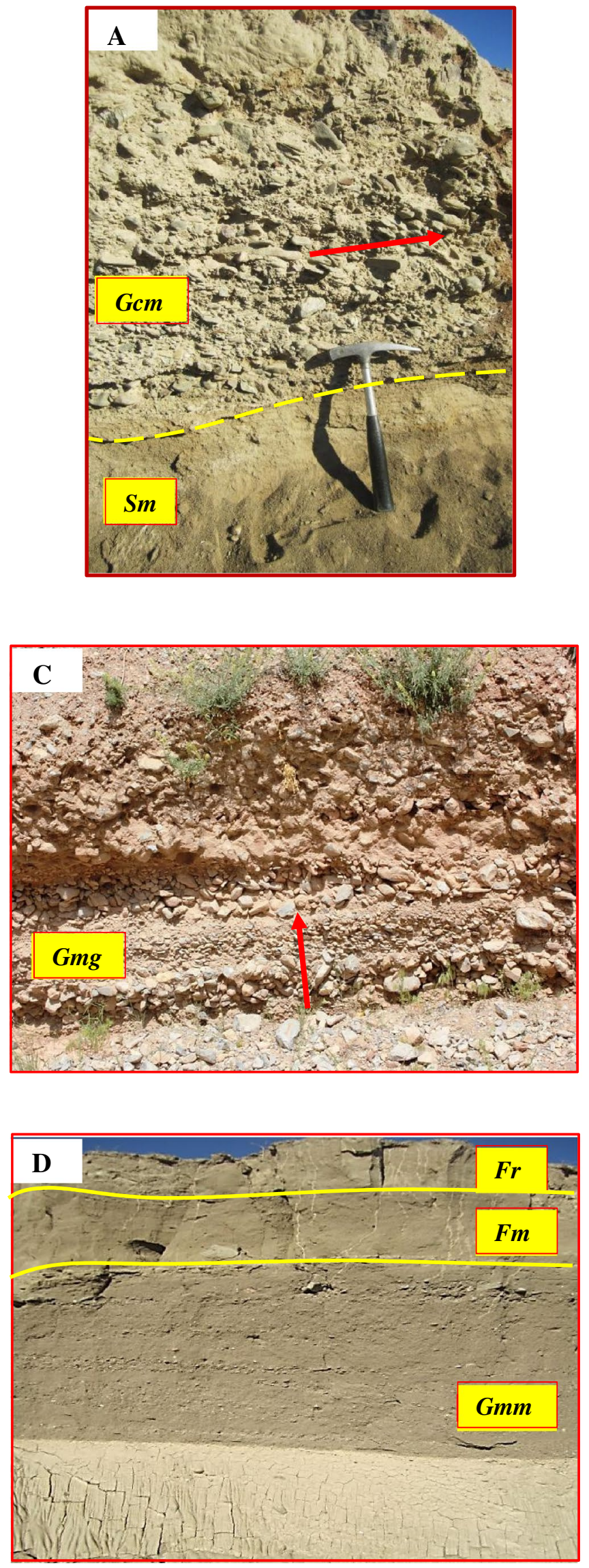

Springer
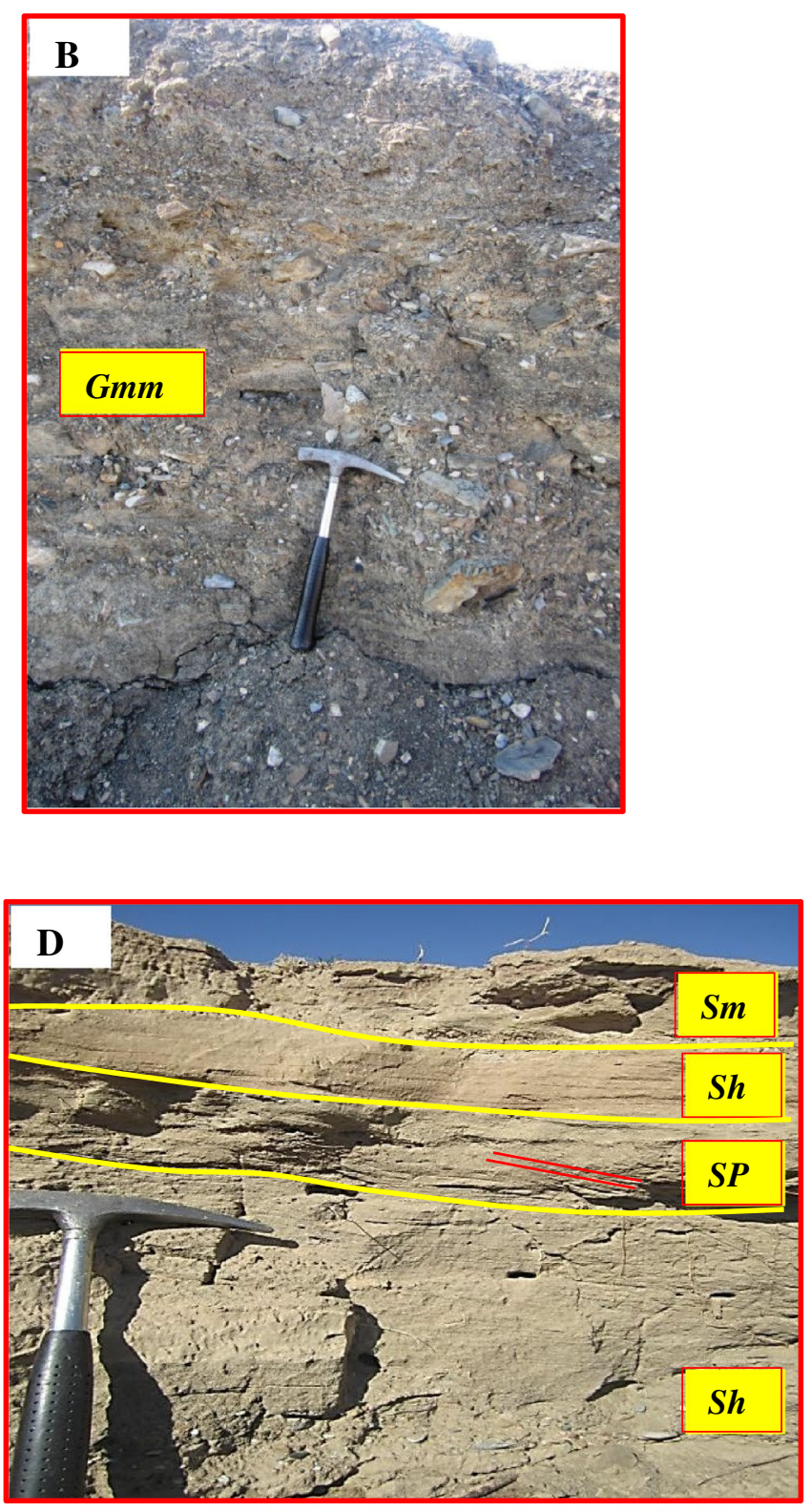
४Fig. 11 Photographs showing lithofacies A clast-supported gravelly and sandy facies ( $\mathrm{Gcm}, \mathrm{Sm}), \mathbf{B}$ matrix-supported gravelly $(\mathrm{Gmm}), \mathbf{C}$ matrix-supported graded bedding gravelly, D sandy facies (Sh, Sm, and $\mathrm{Sp}$ ), E gravelly and mud facies ( $\mathrm{Gmm}, \mathrm{Fm}$, and Fr)

basin is elongated and is characterized by long presentencing flooding. Most of the basin contains steep slope areas, which played a significant role on runoff, infiltration rate, and the intensity of floodings and erosion rates. Also, because of velocity and strength of waters in steep slope areas, these areas are more susceptible to erosion and sediment supply potential. Steep gradients ensure high sediment yield toward the torrent mouth; consequently, a larger area implies greater yield. In contrast, this variable was not related to fan occurrence in basins located at lower altitudes, where gradients are smoother, encouraging the presence of temporal sediment accumulations that delay sediment output. Sediment supply, which is mainly a function of climate, tectonic, and source lithology, is a dominant driver behind the development of rock sequences in the channels of the Ardak basin. The occurrence of Ardak basin is formed in a tectonically active basin (Vernant et al., 2004; Walker and Jackson, 2004) under arid to semiarid climate and a long-term change from wetter to drier conditions. The source-area lithologies of the four channels are coming from sedimentary, respectively, and these channels developed their geometry mainly in response to different weathering intensities of their catchment bedrock lithologies. Severe physical weathering due to daily temperature variation on heterogeneous rocks such as the dolomite and Cretaceous carbonate rocks explain the high amount of dolomite and carbonate fragments in river sediments. Most clasts are subangular to subrounded and poorly sorted due to the short transportation path and steep slope of river wall. Based on topography, three different waterways have been detected in study areas. High lands (high topography) in southern and northern parts of the basin are the reason for dendritic shape of the rivers in that part of the basin, while the peneplain central parts of the basin is characterized by parallel and tributary waterways. The main rivers of Ardak basin and their feeder tributaries have braided channel with steep slope, high-power flows, and short time of flooding's with scarce muddy sediments. Gravel-sized particles generally follow a decreasing trend while sand-sized particles follow an increasing trend, while mud is washed out with continuous flow downstream.

However, discontinuities in graphs are common due to merging of tributaries and changes in the slopes. The great variation in grain size distribution indicates a wide range of hydrodynamic processes acting during deposition of the sediments. Gravelly samples from upstream to downstream of river A, B, and D consist of gravel and sandy gravel. The channel of river $\mathrm{C}$ has lower slope and lower energy flow and the samples consists of muddy sandy gravel. Median and mean graphs indicate that mode is less than median and median is less than mean in some samples, which can be explained by the increase of fine-grained weight percentage in the samples. On the other hand, increasing the mean and median values indicates increase of coarse-grained particles in the samples. Medium to poorly sorted grains in lower parts of channels can be result of debris flows and coarse clasts in these sediments. Typically, sandstone sections are medium sorted; moreover, coarser grains are poorly sorted and vice versa. The overall transition from debris-flow deposits to clast-supported gravels in a river sequence has been interpreted as a record of landscape response to increasing climate aridity (Quigley et al., 2007; Shukla, 2009).

However, in dry land climate, low frequency/high magnitude flood events are normally capable of delivering large amounts of sediments from highland catchment towards the basin outlets and sedimentation in many arid channels is documented as sheet flood, channelized flow as well as debris-flow deposits (Blair, 1999; Arzani, 2005; Waters et al., 2010; Singh et al., 2018). In such climatic settings, sediment transport is not hampered by binding effects of vegetation and episodic very large floods can lead to reshaping of rivers and alluvial fans (Dorn, 2009). The occurrence of intense human pressure until relatively recent times and land use/land cover changes has probably played a role on the Ardak basin. Human occupation usually introduces rapid geomorphic changes and increases sediment yield (GarciaRuiz and Valero-Garces 1998; Kanhaiya, et al., 2017).

On the other hand, sedimentology studies show that in terms of volume, River B, with a length of $24 \mathrm{~km}$, may have a greater role in the production of sediments in the Ardak basin and alluvial fan, but in terms of sediment size, River A can be found in gravelly sediments $(\sim 84)$ considered B more effective in sandy sediments (13.4\%) and mud (4.8\%) (Table 1). From the perspective of the average size of sediments produced in the basin and its role in the average size of sediments, A, D, B, and $\mathrm{C}$ rivers produce more sediments, respectively (Table 2). Since the hard lithologies such as Mozduran 2, Tirgan, and Mozduran 1 are more effective in producing gravel sediments and formations which are mostly composed of shale and marl (such as Shurijeh, Chamanbid, and Sarcheshmeh Formations) are more effective in the production of sand and mud sediments.

Also, fewer slope changes and more hard lithology can be considered the cause of increasing gravel sediments and medium grain size in River A, so that the steep and relatively high slope of this river (Fig. 5) and higher percentage of calcareous and dolomitic sediments (Mozduran 2) and Tirgan (which make up about $88 \%$ of sediments (Table 3 ) as the main factor in this regard).

Marl sediments of Chamanbid Formation are observed in river B and the percentage of sediments of Shurijeh Formation in this river increases (Table 3), and on the other hand, slope changes in at least two parts of this canal which are related to faults in the region. It is a factor in temporarily 
Fig. 12 Palaeocurrent flow direction at different localities of river channels
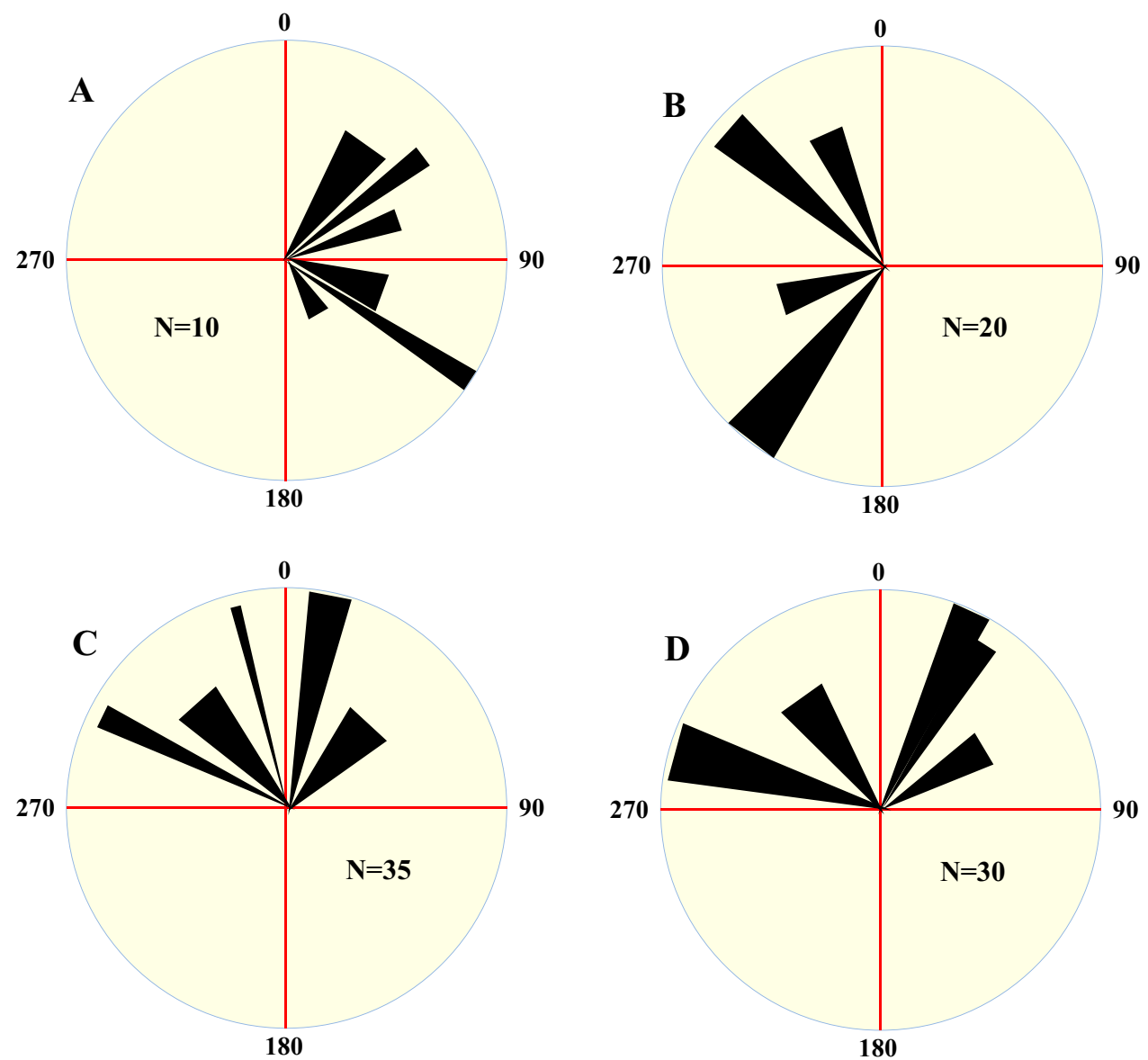

reducing the slope in these areas (Figs. 4 and 7) and has caused more sand and mud sediments than other rivers.

With this interpretation, it can be said that according to the data in Table 3 and Fig. 4, the average size of sediments depends on lithological and tectonic factors and these two factors control other parameters such as slope, vegetation, and water flow intensity. However, the study of sedimentary facies of different rivers in this basin (Fig. 10) and paleocurrent direction (Fig. 12) shows that in the past, in the category of gravel sediments, the rivers B, D, C, and A, respectively, in the sandy category, A, C, D, and $\mathrm{B}$ respectively, and in the muddy category $\mathrm{A}, \mathrm{B}, \mathrm{C}$, and $\mathrm{D}$ have played a greater role. Since the lithology factor, climate, etc., in this basin have been constant over time, so the tectonic factors can be considered the most important factor in controlling the size of sediments in the basin and alluvial fan.

\section{Conclusions}

Ardak basin offers a natural case study for sediment storage, release, and bypass. In that region, the rivers built an outstanding Quaternary alluvial fans and terraces, which have recorded the regional tectonic and climate evolution. In this catchment area, the rivers flowing southward from the mountains have alternatively formed well-developed alluvial fans and incised valleys flanked by terrace. Alluvial deposits constitute a widespread facies in tramontane basins due to strong local uplift and subsidence along faults within actively deforming orogens. Sedimentary deposits in the ardak catchment area show a high degree of diversity because of complex basin geometries, contrasting source areas over short distances, extreme floods events, and different tectonic movements that influence channels geomorphology and facies.

Differential uplift and lithological variations within and between individual channels are combined to determine the sensitivity of individual channels to active tectonics. The drainage basin area, relief, and lithology are intrinsic to the alluvial deposit system, and are independent variables influencing depositional processes, catchment area, and gradient.

The obtained data show that the average size of sediments depends on lithological and tectonic factors and these two factors control other parameters such as slope, vegetation, and water flow intensity. However, the study of sedimentary facies and the paleocurrent direction and its comparison with the data of the present era show that rivers A and B have the greatest impact on the supply of sediments of different grain size categories in this basin and because different factors in This basin has been constant over 
time, so tectonic factors can be considered the most important factor in controlling the size of basin sediments and alluvial fans.

Acknowledgements First of all, I would like to mention the great efforts of my good colleague, Engineer Beheshtipour, in this research, who died due to COVID-19. We would like to express our sincere thanks to Profs. Neil Wells (Kent State University), Gail M. Ashley (Rutgers University), Mark Quigley (University of Canterbury), John J. Clague (Simon Fraser University), Kevin M. Yeager (University of Kentucky), Jeffrey Knott (California State University, Fullerton), Rick Cheel (Brock University), Laura Gonzalez Acebron (University of Madrid), and Stephen Tooth (Aberystwyth University) who reviewed an earlier version of this manuscript and give good comments on the work.

Funding This research is funded by the Regional Water Company of Khorasan Razavi and the Islamic Azad University of Mashhad.

\section{Declarations}

Conflict of interest The authors declare no competing interests.

\section{References}

Aghanabati, A., 2004. Geology of Iran. Geological Survey of Iran publication, $558 \mathrm{pp}$ (in Persian).

Alavi M (1991) Sedimentary and structural characteristics of the Paleo-Tethys remnants in northeastern Iran. Geol Soc Am Bull 103:983-992

Arzani, N., 2005. The fluvialmegafan of Abarkoh basin (central Iran): an example of flash-flood sedimentation in arid lands. In Alluvial Fans: Geomorphology, Sedimentology, Dynamic. Harvey AM, Mather AE, Stokes M (eds). Geological Society of London, Special Publication 251; 41-61.

Arzani N (2012) Catchment lithology as a major control on alluvial megafan development, Kohrud Mountain range, central Iran. Earth Surf Process Landforms 37:726-740

Beaumont P (1972) Alluvial fans along the foothills of the Elburz Mountains, Iran. Palaeogeogr Palaeoclimatol Palaeoecol $12: 251-273$

Berberian M, King GC (1981) Towards a paleogeography and tectonics evolution of Iran. Can J Earth Sci 18:210-265

Blair TC (1999) Sedimentology of gravelly Lake Lahontan highstand shoreline deposits, Churchill Butte, Nevada, USA. Sediment Geol 123:199-218

Bull WB (1991) Geomorphic responses to climatic change. Oxford University Press, New York, p 326

Clarke L, Quine T, Nicholas A (2010) An experimental investigation of autogenic behaviour during alluvial fan evolution. Geomorphology 115:278-285

Calvache M, Viseras C, Fernández J (1997) Controls on alluvial fan development-evidence from fan morphometry and sedimentology; Sierra Nevada, SE Spain. Geomorphology 21:69-84

Chakraborty T, Ghosh P (2010) The geomorphology and sedimentology of the Tista megafan, Darjeeling Himalaya: implications for megafan building processes. Geo-Morphology 115:252-266

Chand MB, Bhattarai BC, Baral P, Pradhananga NS (2019) Trend analysis of temperature data for Narayani river basin. Nepal Science $1: 21$

Dorn, R. I., 2009. The role of climatic change in alluvial fan development. In Geomorphology of Desert Environments 2nd Edition, ed. A.J. Parsons and A.D. Abrahams, Springer, chapter 24, pages 723-742.
Eppes MC, McFadden L (2008) The influence of bedrock weathering on the response of drainage basins and associated alluvial fans to Holocene climates, San Bernardino Mountains, USA. The Holocene 18:895-905

Eftekharnejad J, Behroozi A (1991) Geodynamic significance of recent discoveries of ophiolites and late Paleozoic rocks in NEIran (including Kopet Dagh). Abhandlungen Der Geologischen Bundesanstalt 38:89-100

Folk, R. L., 1980. Petrology of Sedimentary Rocks. Hemphill Publishing, Austin, TX. 182 pp.

Folk RL, Ward WC (1957) Brazo river bar: A study of the significance of grain size parameters. J Sedim Geol 27:3-26

Garcia-Ruiz JM, Valero-Garces BL (1998) Historical geomorphic processes and human activities in the central Spanish Pyrenees. Mt Res Dev 18:309-320

Goswami S, Bhowmik SK, Dasgupta S (2009) Petrology of a nonclassical Barrovian inverted metamorphic sequence from the western Arunachal Himalaya, India. J Asian Earth Sci 36:390-406

Gupta S (1997) Himalayan drainage patterns and the origin of fluvial megafans in the Ganges foreland basin. Geology 25:11-14

Hartley AJ, Chong G, Houston J, Mather AE (2005) 150 million years of climatic stability: evidence from the Atacama Desert, northern Chile. Journal of the Geological Society. J Geol Soc 162:421-424

Hartley AJ, Weissmann GS, Nichols GJ, Warwick GL (2010) Large distributive fluvial systems: characteristics, distribution, and controls on development. J Sediment Res 80:167-183

Harvey A (2002) The relationships between alluvial fans and fan channels within Mediterranean mountain fluvial systems. In: Bull LJ, Kirkby MJ (eds) Dryland Rivers: Hydrology and Geomorphology of Semi-Arid Channels. Wiley, Chichester, pp 205-226

Harvey AM, Mather AE, Stokes M (2005) Alluvial fans: geomorphology, sedimentology, dynamics. Geological Society, London, Special Publications 251:85-94

Harvey AM, Silva PG, Mather AE, Goy JL, Stockes M, Zazo C (1999) The impact of quaternary sea-level and climatic change on coastal alluvial fans in the Cabo de Gata ranges, southeast Spain. Geomorphology 28:1-22

Hollingsworth, J. 2007, The active tectonics of NE Iran, Ph.D. thesis, University of Cambridge, Cambridge, U. K

Horton BK, DeCelles PG (2001) Modern and ancient fluvial megafans in the foreland basin system of the central Andes, southern Bolivia: implications for drainage network evolution in foldthrust belts. Basin Res 13:43-63

Javanbakht M, Ghazi S, Moussavi-Harami R, Mahboubi A (2013) Depositional history and sequence stratigraphy of Tirgan formation (Barremian-Aptian) in central Kopet Dagh, NE Iran. J Geol Soc India 82:701-711

Javanbakht M, Wans HA, Jafarian A, Shahsavan N, Sahraeyan M (2018) Carbonate diagenesis in the Barremian-Aptian Tirgan Formation (Kopet-Dagh Basin, NE Iran): petrographic, geochemical and reservoir quality constraints. J Afr Earth Sc 144:122-135

Juez C, Hassan MA, Franca M (2018) The origin of fine sediment determines the observations of suspended sediment fluxes under unsteady flow conditions. Water Resour Res 54:5654-5669

Kanhaiya S, Singh BP, Tripathi M, Sahu S, Tiwari V (2017) Lithofacies and particle-size characteristics of late quaternary floodplain deposits along the middle reaches of the Ganga river, Uttar Pradesh, India. Geomorphology 284:220-228

Kumar, R., Kumar, R., Singh, A., Singh, S., Bhardwaj, A., Kumari, A., Sinha, R.K., and Gupta, A. 2019. Hydr geochemical analysis of meltwater draining from Bilare Banga glacier, Western Himalaya, Acta Geophysica. 
Leece SA (1991) Influence of lithologic erodibility on alluvial fan area, western White Mountains, California and Nevada. Earth Surf Proc Land 16:11-18

Leier AL, DeCelles PG, Pelletier JD (2005) Mountains, monsoons, and megafans. Geology 33(4):289-292

Levson VM, Rutter NW (2000) Influence of bedrock geology on sedimentation in Pre-Late Wisconsinan alluvial fans in the Canadian Rocky Mountains. Quatern Int 68-71:133-146

Mather AE, Harvey AM, Stokes M (2000) Quantifying long-term catchment changes of alluvial fan systems. Geol Soc Am Bull 112:1825-1833

Miall AD (1996) The geology of fluvial deposits. Springer, Berlin, p 582

Quigley MC, Sandiford M, Cupper ML (2007) Distinguishing tectonic from climatic controls on range-front sedimentation. Basin Res 19:491-505

Robert AMM, Letouzey J, Kavoosi MA, Sherkati S, Müller C, Vergés J, Aghababei A (2014) Structural evolution of the Kopeh Dagh fold-and-thrust-belt (NE Iran) and interactions with the South Caspian Sea Basin and Amu Darya Basin. Mar Pet Geol 57:68-87

Salcher B, Faber R, Wagreich M (2010) Climate as main factor controlling the sequence development of two Pleistocene alluvial fans in the Vienna Basin (eastern Austria) - a numerical modelling approach. Geomorphology 115:215-227

Sheikholeslami MR, Kouhpeyma M (2012) Structural analysis and tectonic evolution of the eastern Binalud Mountains, NE Iran. J Geodyn 61:23-46

Shukla UK, Singh IB, Sharma S, Sharma M (2001) A model of mega fan sedimentation, Ganga Plain, India. Sed Geol 144:243-263

Shukla UK (2009) Sedimentation model of gravel-dominated alluvial piedmont fan, Ganga Plain, India. Int J Earth Sci (geol Rundsch) 98:443-459

Silva P, Harvey AM, Zazo C, Goy JL (1992) Geomorphology, depositional style and morphometric relationships of Quaternary alluvial fans in the Guadalentin Depression (Murcia, Southeast Spain). Zeitschrift Für Geomorphologie Neue Folge 36:325-341

Singh R, Shekhar M, Pandey VK, Kumar R, Sharma RK (2018) Causes and geomorphological effects of large debris flows in the lower valley areas of the Meru and Gangotri glaciers, Bhagirathi basin, Garhwal Himalaya (India). Remote Sensing Lett 9(8):809-818

Stöcklin J (1968) Structural history and tectonics of Iran: a review. Am Asso Petrol Geol Bull 52(7):1229-1258

Stöcklin, J., 1977. Structural correlation of the Alpine ranges between Iran and Central Asia. Mémoire Hors-Série $\mathrm{N}^{\circ} 8$ de la Société Géologique de France, 8, pp. 333-353.

Taheri J, Furcich FT, Wilmsen M (2006) Stratigraphy and depositional environments of theUpper Bajocian-Bathonian Kashafrud Formation (NE Iran). Volumina Jurassica 4:105-106
Thierry, J. 2000. Middle Callovian (157-155 Ma). In: DERCOURT, J., GAETANI,M.ET AL. (eds) AtlasPeri-Tethys Palaeogeographical Maps. CCGM/CGMW, Paris, 71-97.

Thomas JC, Cobbold PR, Shein VS, Le Douaran S (1999) Sedimentary record of Late Paleozoic to Recent tectctonism in central Asiaanalysis of subsurface data from the Turan and South Kazakh domains. Tectonophysics 313:243-263

Trifonov V (1978) Late quaternary tectonic movement of western and central Asia. Geol Soc Am Bull 89:1059-1072

Vernant P, Nilforoushan F et al (2004) Present-day crustal deformation and plate kinematics in Middle East constrained by GPS measurements in Iran and northern Oman. Geophys J Int 157:381-398

Viseras C, Calvache ML, Soria JM, Fernandez J (2003) Differential feactures of alluvial fans controlled by tectonic or eustatic accommodation space. Examples from the Betic Cordillera. Spain Geomorphology 50:181-202

Wagreich, M., Strauss, P. E., 2005. Source area and tectonic control on alluvial fan development in the Miocene Fohnsdorf intramontane basin, Austria. In: HARVEY, A.M., MATHER, A.E. \& STOKES, M. (Eds.): Alluvial Fans: Geomorphology, Sedimentology, Dynamics. Geological Society, London, Special Publications, 251, 207-216.

Walker, R. G., Cant, D. J., 1984. Sandy fluvial systems. In: Walker R. G., (ed): Facies models, 2nd edn, reprint series I. Geological Association of Canada, Toronto, pp 71 -89.

Walker RT, Fattahi M (2011) A framework of Holocene and Late Pleistocene environmental change in eastern Iran inferred from the dating of periods of alluvial fan abandonment, river terracing, and lake deposition. Quatern Sci Rev 30:1256-1271

Walker, R., Jackson, J., 2004. Active tectonics and late Cenozoic strain distribution in central and eastern Iran. Tectonics, 23. https://doi. org/10.1029/2003TC001529.

Waters JV, Jones SJ, Armstrong HA (2010) Climatic controls on late Pleistocene alluvial fans, Cyprus. Geomorphology 115:228-251

Weissmann GS, Mount JF, Fogg GE (2002) Glacially driven cycles in accumulation space and sequence stratigraphy of a streamdominated alluvial fan, San Joaquin Valley, California, U.S.A. J Sediment Res 72:270-281

Wolman MG (1954) A method of sampling coarse fluvial material. Trans.-Am. Geophys Union 35:951-956

Zanchetta S, Berra F, Zanchi A, Bergomi M, Caridroit M, Nicora M, Heidarzadeh G (2013) The record of the Late Palaeozoic active margin of the Palaeotethys in NE Iran: Constraints on the Cimmerian orogeny. Gondwana Res 24:1237-1266

Zanchi, A., Zanchetta, S., Balini, M. and Ghassemi, M. R., (2015) Oblique convergence during the Cimmerian collision: evidencefrom theTriassic Aghdarband basin, NE Iran, Gondwana Research. https://doi.org/10.1016/j.gr.2015.11.008. 